\title{
Mechanisms of dissolved and labile particulate iron supply to shelf waters and phytoplankton blooms off South Georgia, Southern Ocean
}

\author{
Christian Schlosser $^{1,2}$, Katrin Schmidt ${ }^{3,4}$, Alfred Aquilina ${ }^{1}$, William B. Homoky ${ }^{1,5}$, Maxi Castrillejo ${ }^{1,6}$, \\ Rachel A. Mills ${ }^{1}$, Matthew D. Patey ${ }^{1}$, Sophie Fielding ${ }^{3}$, Angus Atkinson ${ }^{3,7}$, and Eric P. Achterberg ${ }^{1,2}$ \\ ${ }^{1}$ Ocean and Earth Science, National Oceanography Centre Southampton, University of Southampton, \\ SO14 3ZH Southampton, UK \\ ${ }^{2}$ GEOMAR Helmholtz Centre for Ocean Research, Wischhofstr. 1-3, 24148 Kiel, Germany \\ ${ }^{3}$ British Antarctic Survey, CB3 0ET Cambridge, UK \\ ${ }^{4}$ School of Geography, Earth and Environmental Sciences, University of Plymouth, PL4 8AA Plymouth, UK \\ ${ }^{5}$ Department of Earth Sciences, University of Oxford, OX1 3AN Oxford, UK \\ ${ }^{6}$ Institut de Ciència i Tecnologia Ambientals \& Departament de Física, Universitat Autònoma de Barcelona, \\ 08193 Bellaterra, Spain \\ ${ }^{7}$ Plymouth Marine Laboratory, Prospect Place, The Hoe, PL1 3DH Plymouth, UK
}

Correspondence: Christian Schlosser (cschlosser@geomar.de)

Received: 14 July 2017 - Discussion started: 28 July 2017

Revised: 18 June 2018 - Accepted: 19 July 2018 - Published: 22 August 2018

\begin{abstract}
The island of South Georgia is situated in the iron (Fe)-depleted Antarctic Circumpolar Current of the Southern Ocean. Iron emanating from its shelf system fuels large phytoplankton blooms downstream of the island, but the actual supply mechanisms are unclear. To address this, we present an inventory of $\mathrm{Fe}$, manganese (Mn), and aluminium (Al) in shelf sediments, pore waters, and the water column in the vicinity of South Georgia, alongside data on zooplankton-mediated $\mathrm{Fe}$ cycling processes, and provide estimates of the relative dissolved $\mathrm{Fe}(\mathrm{DFe})$ fluxes from these sources. Seafloor sediments, modified by authigenic Fe precipitation, were the main particulate Fe source to shelf bottom waters as indicated by the similar $\mathrm{Fe} / \mathrm{Mn}$ and $\mathrm{Fe} / \mathrm{Al}$ ratios for shelf sediments and suspended particles in the water column. Less than $1 \%$ of the total particulate $\mathrm{Fe}$ pool was leachable surface-adsorbed (labile) $\mathrm{Fe}$ and therefore potentially available to organisms. Pore waters formed the primary DFe source to shelf bottom waters, supplying $0.1-44 \mu \mathrm{mol} \mathrm{DFe} \mathrm{m}{ }^{-2} \mathrm{~d}^{-1}$. However, we estimate that only $0.41 \pm 0.26 \mu \mathrm{mol} \mathrm{DFe} \mathrm{m}^{-2} \mathrm{~d}^{-1}$ was transferred to the surface mixed layer by vertical diffusive and advective mixing. Other trace metal sources to surface waters included glacial flour released by melting glaciers and via zooplankton egestion
\end{abstract}

and excretion processes. On average $6.5 \pm 8.2 \mu \mathrm{mol} \mathrm{m}^{-2} \mathrm{~d}^{-1}$ of labile particulate Fe was supplied to the surface mixed layer via faecal pellets formed by Antarctic krill (Euphausia superba), with a further $1.1 \pm 2.2 \mu \mathrm{mol} \mathrm{DFe} \mathrm{m}^{-2} \mathrm{~d}^{-1}$ released directly by the krill. The faecal pellets released by krill included seafloor-derived lithogenic and authigenic material and settled algal debris, in addition to freshly ingested suspended phytoplankton cells.

The $\mathrm{Fe}$ requirement of the phytoplankton blooms $\sim$ $1250 \mathrm{~km}$ downstream of South Georgia was estimated as $0.33 \pm 0.11 \mu \mathrm{mol} \mathrm{m}{ }^{-2} \mathrm{~d}^{-1}$, with the DFe supply by horizontal/vertical mixing, deep winter mixing, and aeolian dust estimated as $\sim 0.12 \mu \mathrm{mol} \mathrm{m}^{-2} \mathrm{~d}^{-1}$. We hypothesize that a substantial contribution of $\mathrm{DFe}$ was provided through recycling of biogenically stored $\mathrm{Fe}$ following luxury Fe uptake by phytoplankton on the Fe-rich shelf. This process would allow $\mathrm{Fe}$ to be retained in the surface mixed layer of waters downstream of South Georgia through continuous recycling and biological uptake, supplying the large downstream phytoplankton blooms. 


\section{Introduction}

The Southern Ocean is the largest "high-nitrate, lowchlorophyll" (HNLC) region of the global ocean (Buesseler et al., 2004), as a consequence of low iron (Fe) supply and consequently reduced phytoplankton growth (Buesseler et al., 2004; Tsuda et al., 2009). Iron can be supplied to surface waters of the Southern Ocean by atmospheric dust inputs (Cassar et al., 2007; Gao et al., 2001), horizontal/vertical advective and diffusive mixing processes (de Jong et al., 2012), resuspension from shelf sediments (Kalnejais et al., 2010; Marsay et al., 2014), melting of icebergs and glaciers (Raiswell et al., 2008), and hydrothermal inputs (German et al., 2016). Despite the overall HNLC status of the Southern Ocean, regions in the wake of islands feature large seasonal phytoplankton blooms; the $\mathrm{Fe}$ sources to these blooms are however poorly constrained (de Jong et al., 2012; Planquette et al., 2007; Pollard et al., 2009).

Downstream of the island of South Georgia intense, longlasting phytoplankton blooms have been observed which extend hundreds of kilometres and require an enhanced Fe supply. The blooms peak in austral summer (Borrione et al., 2014), stretch over an area of $\sim 750000 \mathrm{~km}^{2}$ (Atkinson et al., 2001; Korb et al., 2004), and are responsible for the largest dissolved inorganic carbon deficit reported within the Antarctic Circumpolar Current (ACC) (Jones et al., 2012, 2015). As a consequence of the Fe fertilization, the waters in the vicinity of South Georgia support extensive phytoplankton blooms and a large biomass of zooplankton, fish, seabirds, and marine mammals, some of which are exploited commercially (Atkinson et al., 2001; Murphy et al., 2007).

South Georgia forms part of the volcanically active Scotia Arc in the Atlantic sector of the Southern Ocean and is surrounded by a broad $30-100 \mathrm{~km}$ wide shelf with an average (albeit highly variable) depth of ca. $200 \mathrm{~m}$ (Fig. 1). The island is situated between the Antarctic Polar Front (PF) and the Southern ACC Front (SACCF), within the general northeast flow of the ACC (Meredith et al., 2005; Whitehouse et al., 2008). The ACC surface waters are enriched in nitrate, phosphate, and silicic acid, but strongly depleted in most trace elements, notably $\mathrm{Fe}$ and manganese $(\mathrm{Mn})$ (Browning et al., 2014). The large seasonal phytoplankton blooms downstream of South Georgia are thought to be supplied with $\mathrm{Fe}$ from the island during the passage of ACC waters (Borrione et al., 2014; Nielsdóttir et al., 2012).

In this study we provide the first comprehensive data set of dissolved and (labile) particulate $\mathrm{Fe}, \mathrm{Mn}$, and aluminium (Al) in sediments, pore waters, and the water column overlaying the shelf and shelf edge regions of South Georgia. We also include published data on the role of Antarctic krill in new Fe supply and recycling in this region (Schmidt et al., 2011, 2016). We discuss differences between the various analysed trace metal fractions and the supply routes of dissolved and (labile) particulate $\mathrm{Fe}$, such as sedimentary pore water efflux, supply of sediment-derived particulate Fe to the surface mixed layer, efflux of Fe from glacial melting, and supply of Fe by faecal pellets of Antarctic krill. Furthermore, we discuss the productivity of the bloom region to the north of South Georgia in relation to the estimated Fe supply rates.

\section{Methods}

\subsection{Cruises and sampling}

Samples were collected during three research cruises to South Georgia in 2011 (JR247, JC055) and 2013 (JR274). While cruises JR247 and JR274 aimed to examine the pelagic shelf ecosystem by collection of predominantly water samples (and zooplankton during JR247) on the northern shelf, JC055 explored solely the composition of sediments on the South Georgia shelf. Cruise JR247 took place in January 2011 on RRS James Clark Ross, and 14 sites on the northern shelf and shelf edge of South Georgia were visited (stations 1-21; Fig. 1). Suspended particles were collected on acid-cleaned polycarbonate filters $(1 \mu \mathrm{m}$ pore size; Whatman) using in situ stand-alone pumping systems (SAPSs; Challenger Oceanic) attached to a Kevlar wire and deployed at 20, 50, and $150 \mathrm{~m}$ depth (Fig. 1, red dots). The filters were rinsed with deionized water (Milli-Q; Millipore), stored at $-20^{\circ} \mathrm{C}$, and shipped frozen to the National Oceanography Centre Southampton (NOCS).

Subsurface seawater samples were collected by trace metal clean samplers (Ocean Test Equipment (OTE)) at 9 of the 14 SAPS locations (Fig. 1; black stars). Seawater samples were filtered using cartridge filter $(0.2 \mu \mathrm{m}$ Sartobran P 300, Sartorius) into acid-cleaned $125 \mathrm{~mL}$ low-density polyethylene (LDPE) bottles (Nalgene). Unfiltered samples were collected in $125 \mathrm{~mL}$ LDPE bottles for analysis of total dissolvable (TD) trace metals. Surface waters from the South Georgia shelf were collected using a tow fish deployed alongside the ship at 3-4 m depth. Samples were filtered in line using a cartridge filter $(0.2 \mu \mathrm{m}$ Sartobran P 300, Sartorius) and dispensed in acid-washed $125 \mathrm{~mL}$ LDPE bottles. Unfiltered surface seawater samples were also collected and dispensed in acid-washed $125 \mathrm{~mL}$ LDPE bottles. All seawater samples were acidified on board with ultra-clean $\mathrm{HNO}_{3}(15 \mathrm{M} \mathrm{UpA}$ grade, Romil) to $\mathrm{pH} 1.7\left(22 \mu \mathrm{mol} \mathrm{H}^{+} \mathrm{L}^{-1}\right)$. For a more detailed description of all sample-handling procedures, please see Sect. S1 in the Supplement.

In January and February 2013, RRS James Clark Ross cruise JR274 revisited South Georgia and collected surface seawater samples covering the shelf, shelf edge, and openocean areas around the island. Dissolved and TD trace elements in surface seawater samples were collected using the tow fish and treated similarly to samples from JR247. For a more detailed description of all sample-handling procedures, please see Sect. S1.

During the RRS James Cook cruise JC055 in February 2011, a megacorer (Bowers and Connelly type) was used 

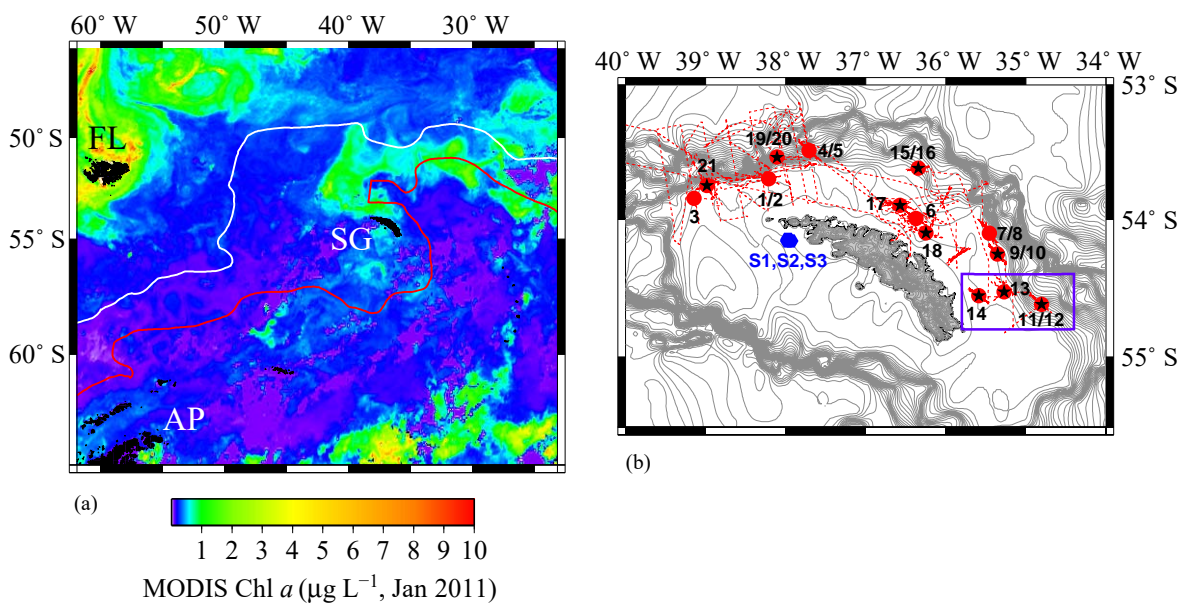

(b)

Figure 1. (a) Locations of Falkland Islands (FL), South Georgia (SG), and Antarctic Peninsula (AP) in the Atlantic sector of the Southern Ocean. South Georgia is located between the Antarctic Polar Front (PF, white line) and the Southern Arctic Circumpolar Current Front (SACCF, red line). The colour bar represents the Chlorophyll $a(\mathrm{Chl} a)$ content recorded by the MODIS satellite in January 2011. (b) The region around SG and the OTE (black stars) and SAPS sampling sites (red points) visited during JR247. The red dashed line illustrates the cruise track of JR247. The three sediment sampling sites visited during JC055 (S1, S2, and S3) are shown by blue hexagons. The purple box indicates the $\mathrm{W}-\mathrm{E}$ transect from shelf site \#14 via site \#13 to the shelf edge site \#11/12. The ocean bathymetry of the region was plotted using the GEBCO bathymetric data set. The shelf of South Georgia is between 100 and $250 \mathrm{~m}$ deep and extends about 30 to $100 \mathrm{~km}$ (shelf edge indicated by high density of isobaths).

to collect surface sediment and pore water samples on the southern side of South Georgia (there was no opportunity to sample the northern side of the island). Cores representing the intact sediment-water interface were retrieved from three sites on the southern shelf, at water depths of ca. $250 \mathrm{~m}$ (S1-S3) (Fig. 1, blue hexagons). Pore waters were separated by centrifugation under $\mathrm{N}_{2}$ atmosphere and filtered using cellulose nitrate syringe filters $(0.2 \mu \mathrm{m}$ pore size, Whatman; Homoky et al., 2012). Conjugate sediments were freezedried on board and stored at room temperature. A more detailed description of sediment and pore water samplehandling procedures is provided in Sect. S2.

Krill faecal pellets were obtained during on-board krill incubations performed during JR247. Incubations were performed in darkness in the laminar flow cabinet at ambient surface layer temperature. The krill were incubated in filtered seawater from the tow fish for up to $\sim 3 \mathrm{~h}$ immediately after capture, so that pellets obtained derived from material ingested in situ. These incubations and their results are described in more detail in Schmidt et al. (2016).

\subsection{Trace metal analysis in suspended particles and krill faecal pellets}

The labile trace metal fraction of suspended particles (SAPS) and krill faecal pellets was remobilized using a 25\% acetic acid solution (glacial SpA, Romil) following Planquette et al. (2011). The labile trace metal fraction is hereafter referred to as the leachable trace metal fraction $(L)$. The remaining particles were digested on a hot plate, applying a mixture of aqua regia and hydrogen fluoride (Planquette et al., 2011). This fraction will be referred to as the refractory fraction $(R)$. The particulate trace metal fraction $(P)$ is the sum of leachable $(L)$ and refractory $(R)$ fractions. All samples were analysed by collision cell inductively coupled plasma-mass spectrometry (ICP-MS) (Thermo Fisher Scientific, XSeriesII). For a more detailed description of measured certified reference material see Sect. S1.

\subsection{Trace metal analysis of seawater}

The filtered and unfiltered seawater samples were stored for a period of 12 months prior to analysis. Concentrations of dissolved and total dissolvable $\mathrm{Fe}, \mathrm{Mn}$, and $\mathrm{Al}$ in seawater were determined by offline pre-concentration and isotope dilution/standard addition ICP-MS (Thermo Fisher Scientific Element2 XR) according to Rapp et al. (2017). For a more detailed description of the method and measured reference materials see Sect. S1.

\subsection{Trace metal analysis of pore waters and sediments}

Sub-samples of the bulk homogenized sediments were fully dissolved following an aqua regia and combined hydrofluoric-perchloric acid digestion method following Homoky et al. (2011). The acid digests and pore waters were analysed by ICP-optical emission spectrometry (OES) (Perkin Elmer Optima 4300DV). For a more detailed description of the method and measured reference materials see Sect. S2. 


\section{Results \& discussion}

\subsection{Supply routes of suspended particulate $\mathrm{Fe}, \mathrm{Mn}$, and Al}

To avoid confusion, we will now define the terms biogenic, lithogenic, and authigenic particles, as they will be used frequently in the following sections. Biogenic particles refer to suspended organic particles, living and dead, such as phytoplankton cells. Lithogenic particles comprise mineral fragments, such as glacial flour and sediment particles. Authigenic particle include surface-scavenged trace metals and secondary minerals, such as amorphous $\mathrm{FeO}(\mathrm{OH})$ (e.g. goethite), that are formed in seawater and because of their age are insoluble to weak acid leaches (e.g. $25 \%$ acetic acid solution).

\subsubsection{Characterization of (the two) particulate trace metal fractions}

Two different particulate fractions were obtained from samples collected during JR247: a particulate fraction from suspended particles collected using $1 \mu \mathrm{m}$ pore size SAPS filters $(P)$ and a leachable particulate fraction from unfiltered acidified seawater samples $\left(\mathrm{LP}_{\mathrm{Un}}\right)$ collected at the same depth. $\mathrm{LP}_{\text {Un }}$ was calculated following Eq. (1):

$$
\begin{aligned}
\mathrm{LP}_{\mathrm{Un}} & =\text { total dissolvable }(\mathrm{TD} ; \text { unfiltered }) \\
& - \text { dissolved }(D ; 0.2 \mu \mathrm{m} \text { filtered }) .
\end{aligned}
$$

Because of the different sampling approaches (SAPS vs. OTE water samplers), filter sizes ( $>1 \mu \mathrm{m}$ for SAPS vs. $>0.2 \mu \mathrm{m}$ for dissolved seawater), and digestion procedures (aqua regia $+\mathrm{HF}$ for SAPS particles vs. water sample storage at $\mathrm{pH} 1.7\left[22 \mu \mathrm{mol} \mathrm{H}^{+} \mathrm{L}^{-1}\right]$ ), concentrations of $\mathrm{LP}_{\mathrm{Un}}$ and $P$ differed, but they showed similar distribution patterns in the water column (Figs. 2 and S1 in the Supplement, Tables 1 and 2). The concentrations of $\mathrm{Fe}, \mathrm{Mn}$, and $\mathrm{Al}$ in the $\mathrm{LP}_{\mathrm{Un}}$ fraction $\left(\mathrm{LP}_{\mathrm{Un}} \mathrm{Fe}, \mathrm{LP}_{\mathrm{Un}} \mathrm{Mn}, \mathrm{LP}_{\mathrm{Un}} \mathrm{Al}\right)$ were usually slightly lower than the particulate fraction from suspended particles ( $\mathrm{PFe}, \mathrm{PMn}, \mathrm{PAl})$. The $\mathrm{LP}_{\mathrm{Un}}$ of unfiltered seawater samples corresponded to $\sim 63 \pm 4 \%$ of the $\mathrm{PFe}, 83 \pm 11 \%$ of the PAl, and nearly $100 \pm 10 \%$ of the PMn fractions obtained by SAPS. The average $\mathrm{LP}_{\mathrm{Un}}$ trace metal ratios $\left(\mathrm{LP}_{\mathrm{Un}} \mathrm{Fe} / \mathrm{LP}_{\mathrm{Un}} \mathrm{Mn}=33.07 \pm 3.45(1 \sigma)\right.$ and $\left.\mathrm{LP}_{\mathrm{Un}} \mathrm{Fe} / \mathrm{LP}_{\mathrm{Un}} \mathrm{Al}=0.65 \pm 0.10(n=69)\right)$ were about half of the elemental ratios of suspended particles obtained by SAPS $(\mathrm{PFe} / \mathrm{PMn}=68.0 \pm 0.6$ and $\mathrm{PFe} / \mathrm{PAl}=1.251 \pm 0.042(n=$ 42) (Fig. 3; Tables 1, 2 and 3)).

The lower concentrations of $\mathrm{Fe}$ and $\mathrm{Al}$ and the reduced elemental ratios in the $\mathrm{LP}_{\mathrm{Un}}$ compared to the $P$ fractions suggest that an unknown fraction of particulate $\mathrm{Fe}$ and $\mathrm{Al}$ in seawater was not leached during the acidification procedure at pH 1.7 over 12 months. However, since $P$ and $\mathrm{LP}_{\mathrm{Un}}$ displayed similar trends with depth (Figs. 2 and S1), LP $_{\text {Un }}$ was used in Sect. 3.1.3 and 3.3 as an indicator for the abundance of particulate trace metals at locations where particulate samples could not be retrieved by SAPS, e.g. in surface waters collected by the tow fish and depths greater than $150 \mathrm{~m}$.

\subsubsection{Suspended particulate trace metals in the water column}

Concentrations of $\mathrm{PFe}, \mathrm{PMn}$, and $\mathrm{PAl}$ in the water column ranged from 0.87 to $267,0.01$ to 3.85 , and 0.60 to $195 \mathrm{nmol} \mathrm{L}^{-1}$, respectively (Fig. 2, Table 2). Concentrations of $\mathrm{LP}_{\mathrm{Un}} \mathrm{Fe}, \mathrm{LP}_{\mathrm{Un}} \mathrm{Mn}$, and $\mathrm{LP}_{\mathrm{Un}} \mathrm{Al}$ ranged from 1 to $118,0.01$ to 100 , and 1 to $141 \mathrm{nmol} \mathrm{L}^{-1}$, respectively (Fig. 2, Table 1). Below the isopycnal density layer $27.05 \mathrm{~kg} \mathrm{~m}^{-3}$, located at $\sim 50-70 \mathrm{~m}$ depth, $P$ and $\mathrm{LP}_{\mathrm{Un}}$ increased with depth and showed a maximum near the seafloor of e.g. $207 \mathrm{nmol} \mathrm{L}^{-1}$ for $\mathrm{PFe}$ and $112 \mathrm{nmol} \mathrm{L}^{-1}$ for $\mathrm{LP}_{\mathrm{Un}} \mathrm{Fe}$ (\#17, Table 2). Most sites on the shelf (bottom depth $\leq 260 \mathrm{~m}$; \#9/10, \#13, \#14, $\# 17$, and \#21) showed seafloor maxima, in agreement with other shelf studies. For example, Milne et al. (2017) reported concentrations of up to $140 \mathrm{nmol} \mathrm{L}^{-1}$ for $\mathrm{PFe}$ and $800 \mathrm{nmol} \mathrm{L}^{-1}$ for PAl in bottom waters on the west African shelf, and Chase et al. (2005) showed bottom water maxima of up to $400 \mathrm{nmol} \mathrm{L}^{-1}$ for $\mathrm{LP}_{\mathrm{Un}} \mathrm{Fe}$ off the Oregon coast.

Strong linear relationships between elements were observed for suspended particles (SAPS) obtained from above and below the $27.05 \mathrm{~kg} \mathrm{~m}^{-3}$ isopycnal, with elemental ratios of $\mathrm{PFe} / \mathrm{PMn}=68.0 \pm 0.6, \mathrm{PFe} / \mathrm{PAl}=1.25 \pm 0.04$, and $\mathrm{PMn} / \mathrm{PAl}=0.0171 \pm 0.0041 \quad(n=42) \quad$ (Fig. 3, Tables 2 and 3). These elemental ratios were higher than those reported for the earth's crust $(\mathrm{Fe} / \mathrm{Mn}=58.0, \mathrm{Fe} / \mathrm{Al}=0.2$, $\mathrm{Mn} / \mathrm{Al}=0.0035$; Wedepohl, 1995) and sediment samples collected to the south of the island (mean sediment surface layer of S1, S2, S3; SFe $/ \mathrm{SMn}=51.5 \pm 2.4, \mathrm{SFe} / \mathrm{SAl}=$ $0.34 \pm 0.02, \mathrm{SMn} / \mathrm{SAl}=0.0066 \pm 0.0002$ (Fig. 4, Tables 3 and 4)), suggesting that the suspended particles were more enriched in Fe than crustal and lithogenic particles (Table 3).

The Fe / Mn ratios among different phytoplankton species show strong variations but are typically much lower $(\mathrm{Fe} / \mathrm{Mn}$ $\sim 1.7$; Ho et al., 2003), with also lower Fe concentrations than lithogenic (sediment) particles (cellular Fe concentration of phytoplankton $\sim 0.7 \mathrm{mmol} \mathrm{kg}^{-1}$, Ho et al., 2003; upper crust $\sim 550 \mathrm{mmol} \mathrm{kg}^{-1}$, Wedepohl, 1995)). A prevalence of biogenic particles in the suspended particle pool would be expected to result in reduced PFe / PMn ratios in our SAPS samples to values less than 51.5 , as observed in the sediments.

It is most likely that authigenic Fe precipitation (e.g. dissolved $\mathrm{Fe}$ (DFe) was scavenged onto sediment particles) increased the Fe-to-Al (and Fe-to-Mn) ratio of suspended particles $(\mathrm{PFe} / \mathrm{PAl}=1.25 ; \mathrm{PFe} / \mathrm{PMn}=68.0)$ compared to sediment particles $(\mathrm{SFe} / \mathrm{SAl}=0.34 ; \mathrm{SFe} / \mathrm{SMn}=51.5)$. At seawater $\mathrm{pH}(\sim \mathrm{pH} 8)$, dissolved $\mathrm{Fe}(\mathrm{III})$ is rapidly hydrolysed to soluble $\mathrm{Fe}(\mathrm{III})(\mathrm{OH})_{3}(<0.02 \mu \mathrm{m})$, which readily accumulates as nanometre-sized colloids $(0.02-0.2 \mu \mathrm{m})$ (Liu 
Table 1. OTE seawater samples: Fe, Mn, and Al concentrations determined for the dissolved $(D)(0.2 \mu \mathrm{m})$ and the leachable particulate fraction (LP $\mathrm{Un}_{\mathrm{n}}$ ) (total dissolvable-dissolved) of unfiltered seawater samples collected during JR247. Additional information covers sampling date, site (station) ID, event number, and latitude and longitude.

\begin{tabular}{|c|c|c|c|c|c|c|c|c|}
\hline \multirow[t]{2}{*}{ Date } & \multirow{2}{*}{$\begin{array}{l}\text { Site ID } \\
\text { lat., long. }\end{array}$} & \multirow{2}{*}{$\begin{array}{l}\text { Depth } \\
(\mathrm{m})\end{array}$} & \multicolumn{3}{|c|}{ Leach. part. $\left(\mathrm{nmol} \mathrm{L}^{-1}\right)$} & \multicolumn{3}{|c|}{ Dissolved $\left(\mathrm{nmol} \mathrm{L}^{-1}\right)$} \\
\hline & & & $\mathrm{LP}_{\mathrm{Un}} \mathrm{Fe}$ & $\mathrm{LP}_{\mathrm{Un}} \mathrm{Mn}$ & $\mathrm{LP}_{\mathrm{Un}} \mathrm{Al}$ & $\mathrm{DFe}$ & DMn & DAl \\
\hline \multirow[t]{6}{*}{ 04/01/2011 } & \#9/10 (E95 \& E97) & 20 & 20.36 & 0.95 & 46.41 & 5.71 & 1.83 & 1.11 \\
\hline & & 50 & 15.18 & 0.42 & 40.86 & 3.19 & 1.88 & 2.27 \\
\hline & $54.26^{\circ} \mathrm{S}, 35.35^{\circ} \mathrm{W}$ & 100 & 9.86 & 0.23 & 20.43 & 1.55 & 0.92 & 2.07 \\
\hline & & 130 & 23.33 & 0.73 & 48.91 & 2.82 & 0.87 & 2.68 \\
\hline & & 150 & 23.71 & 0.43 & 46.95 & 2.35 & 1.03 & 0.12 \\
\hline & & 200 & 27.37 & 0.62 & 54.41 & 2.70 & 0.89 & 2.37 \\
\hline \multirow[t]{12}{*}{ 05/01/2011 } & $\# 11 / 12$ (E98 \& E101) & 20 & 4.05 & 0.38 & 6.68 & 2.19 & 0.41 & 3.57 \\
\hline & & 35 & 1.52 & 0.39 & 7.28 & 0.41 & 0.37 & - \\
\hline & $54.62^{\circ} \mathrm{S}, 34.81^{\circ} \mathrm{W}$ & 50 & 9.30 & 0.60 & 22.20 & 7.18 & 0.64 & 13.31 \\
\hline & & 75 & 1.28 & 0.31 & 7.85 & 0.77 & 0.35 & 4.56 \\
\hline & & 100 & 2.02 & 0.32 & 3.34 & 1.09 & 0.35 & 1.47 \\
\hline & & 150 & 1.55 & 0.38 & 3.18 & 1.10 & 0.45 & - \\
\hline & & 200 & 13.10 & 1.31 & 23.81 & 1.26 & 1.17 & 3.07 \\
\hline & & 300 & 8.62 & 0.70 & 23.25 & 1.06 & 0.55 & - \\
\hline & & 400 & 8.81 & 0.54 & 16.54 & 2.05 & 0.46 & 2.69 \\
\hline & & 500 & 4.51 & 0.41 & 11.41 & 0.72 & 0.38 & 0.76 \\
\hline & & 600 & 2.75 & 0.37 & 10.32 & 0.96 & 0.36 & 0.77 \\
\hline & & 700 & 4.81 & 0.41 & 16.85 & 0.82 & 0.35 & - \\
\hline \multirow[t]{5}{*}{ 06/01/2011 } & \#13 (E105) & 20 & 3.46 & 0.62 & 14.68 & 0.28 & 0.57 & 4.53 \\
\hline & & 35 & 1.00 & 0.33 & 7.17 & 0.10 & 0.28 & 2.64 \\
\hline & $54.53^{\circ} \mathrm{S}, 35.27^{\circ} \mathrm{W}$ & 50 & 7.09 & 0.71 & 22.62 & 1.26 & 0.57 & 5.77 \\
\hline & & 75 & 25.03 & 1.09 & 61.94 & 1.23 & 0.64 & 5.86 \\
\hline & & 100 & 34.06 & 1.30 & 87.43 & 0.82 & 0.74 & 4.08 \\
\hline \multirow[t]{6}{*}{ 07/01/2011 } & \#14 (E113) & 20 & 4.00 & 0.89 & 7.87 & 0.64 & 0.85 & 2.57 \\
\hline & & 50 & 2.23 & 0.31 & 7.64 & 0.27 & 0.32 & 1.80 \\
\hline & $54.56^{\circ} \mathrm{S}, 35.59^{\circ} \mathrm{W}$ & 75 & 2.30 & 0.43 & 3.58 & 0.62 & 0.46 & 2.42 \\
\hline & & 100 & 2.26 & 0.44 & 3.34 & 0.35 & 0.46 & 0.46 \\
\hline & & 150 & 23.50 & 0.94 & 33.35 & 0.70 & 0.62 & 0.23 \\
\hline & & 200 & 82.26 & 2.12 & 103.11 & 2.69 & 0.77 & 2.31 \\
\hline \multirow[t]{12}{*}{ 08/01/2011 } & $\# 15 / 16$ (E119 \& E129) & 20 & 17.66 & 0.46 & 26.66 & 0.99 & 1.36 & - \\
\hline & & 35 & 16.60 & 0.30 & 13.37 & 0.96 & 1.27 & - \\
\hline & $53.62^{\circ} \mathrm{S}, 36.34^{\circ} \mathrm{W}$ & 50 & 16.30 & 0.23 & 18.49 & 1.21 & 1.40 & - \\
\hline & & 75 & 23.82 & 0.56 & 29.86 & 0.98 & 1.28 & - \\
\hline & & 100 & 8.49 & 0.10 & 10.50 & 0.73 & 0.56 & - \\
\hline & & 150 & 1.88 & 0.03 & 4.49 & 2.25 & 0.40 & - \\
\hline & & 200 & 2.72 & 0.02 & 1.40 & 0.63 & 0.44 & 2.87 \\
\hline & & 300 & 2.56 & 0.05 & 2.40 & 0.34 & 0.25 & - \\
\hline & & 400 & 3.75 & 0.02 & 5.28 & 0.48 & 0.30 & 1.17 \\
\hline & & 500 & 5.28 & 0.08 & 9.22 & 0.43 & 0.30 & - \\
\hline & & 600 & 5.50 & 0.09 & 11.45 & 0.53 & 0.28 & 1.63 \\
\hline & & 750 & 5.27 & 0.06 & 8.16 & 0.44 & 0.30 & - \\
\hline \multirow[t]{6}{*}{$10 / 01 / 2011$} & \#17 (E133) & 20 & 10.92 & 0.22 & 7.43 & 2.31 & 1.20 & 3.76 \\
\hline & & 35 & 20.83 & 0.53 & 16.22 & 1.81 & 1.34 & 2.56 \\
\hline & $53.90^{\circ} \mathrm{S}, 36.57^{\circ} \mathrm{W}$ & 50 & 34.59 & 1.00 & 57.55 & 2.29 & 1.42 & 2.33 \\
\hline & & 75 & 118.25 & 2.18 & 64.36 & 4.21 & 1.86 & 2.19 \\
\hline & & 100 & 50.71 & 1.00 & 77.52 & 2.48 & 1.42 & 1.62 \\
\hline & & 150 & 112.28 & 2.23 & 86.09 & 3.39 & 1.41 & 0.86 \\
\hline
\end{tabular}


Table 1. Continued.

\begin{tabular}{|c|c|c|c|c|c|c|c|c|}
\hline \multirow[t]{2}{*}{ Date } & \multirow{2}{*}{$\begin{array}{l}\text { Site ID } \\
\text { lat., long. }\end{array}$} & \multirow{2}{*}{$\begin{array}{r}\text { Depth } \\
(\mathrm{m})\end{array}$} & \multicolumn{3}{|c|}{ Leach. part. $\left(\mathrm{nmol} \mathrm{L}^{-1}\right)$} & \multicolumn{3}{|c|}{ Dissolved $\left(\mathrm{nmol} \mathrm{L}^{-1}\right)$} \\
\hline & & & $\mathrm{LP}_{\mathrm{Un}} \mathrm{Fe}$ & $\mathrm{LP}_{\mathrm{Un}} \mathrm{Mn}$ & $\mathrm{LP}_{\mathrm{Un}} \mathrm{Al}$ & $\mathrm{DFe}$ & DMn & DAl \\
\hline \multirow[t]{6}{*}{$11 / 01 / 2011$} & \#18 (E138) & 20 & 106.71 & 1.77 & 95.17 & 2.75 & 1.57 & 3.36 \\
\hline & & 35 & 83.53 & 0.00 & 100.32 & 1.97 & 1.33 & 2.44 \\
\hline & $54.10^{\circ} \mathrm{S}, 36.25^{\circ} \mathrm{W}$ & 50 & 9.67 & 0.00 & 18.23 & 0.74 & 0.85 & - \\
\hline & & 75 & 5.65 & 0.00 & 8.90 & 0.62 & 0.65 & - \\
\hline & & 100 & 4.50 & 0.08 & 23.65 & 1.25 & 0.48 & 5.18 \\
\hline & & 150 & 7.81 & 0.11 & 12.87 & 1.43 & 0.49 & 8.19 \\
\hline \multirow[t]{10}{*}{$12 / 01 / 2011$} & $\# 19 / 20($ E141 \& E143) & 20 & 60.19 & 2.11 & 54.29 & 1.46 & 1.71 & 5.30 \\
\hline & & 35 & 60.17 & 2.19 & 87.17 & 1.34 & 1.90 & 8.22 \\
\hline & $53.54^{\circ} \mathrm{S}, 38.11^{\circ} \mathrm{W}$ & 50 & 66.78 & 2.74 & 141.75 & 1.57 & 1.90 & 8.73 \\
\hline & & 75 & 71.69 & 1.78 & 79.19 & 1.61 & 2.13 & 11.45 \\
\hline & & 100 & 10.77 & 0.25 & 32.12 & 0.99 & 0.67 & 10.74 \\
\hline & & 150 & 5.43 & 0.13 & 31.35 & 1.84 & 0.92 & 12.00 \\
\hline & & 200 & 7.92 & 0.14 & 27.42 & 1.45 & 0.60 & 9.60 \\
\hline & & 400 & 5.35 & 0.00 & 23.61 & 1.61 & 0.45 & 18.44 \\
\hline & & 600 & 5.81 & 0.10 & 35.99 & 1.06 & 0.38 & 10.74 \\
\hline & & 800 & 4.26 & 0.13 & 35.67 & 1.07 & 0.36 & 11.95 \\
\hline \multirow[t]{6}{*}{$13 / 01 / 2011$} & \#21 (E151) & 20 & 44.75 & 1.54 & 114.13 & 0.72 & 1.38 & 2.58 \\
\hline & & 35 & 39.99 & 1.82 & 73.37 & 0.77 & 0.94 & 2.29 \\
\hline & $53.75^{\circ} \mathrm{S}, 38.98^{\circ} \mathrm{W}$ & 50 & 48.57 & 2.03 & 94.66 & 1.24 & 1.36 & 1.91 \\
\hline & & 75 & 25.63 & 0.91 & 68.56 & 0.98 & 1.17 & - \\
\hline & & 100 & 64.06 & 1.91 & 114.03 & 2.33 & 1.32 & 1.51 \\
\hline & & 150 & 73.04 & 1.59 & 62.83 & 7.70 & 1.28 & 12.20 \\
\hline
\end{tabular}

and Millero, 2002) and particles (>0.2 $\mu \mathrm{m}$ ) (own observation). It has also been shown that both soluble and colloidal $\mathrm{Fe}$ are attracted by charged surfaces (organic and inorganic particle surfaces), a process that removes DFe and simultaneously increases the amount of particulate $\mathrm{Fe}$ in seawater over time (Schlosser et al., 2011).

A range of mechanisms deliver suspended particles to the surface waters. These transport mechanisms will be discussed in the following section.

\subsubsection{Glacial outflow and zooplankton feeding activity}

While most stations on the shelf showed bottom water maxima of particulate metals, at three sampling sites located on the shelf (\#18) and shelf edge (\#15/16 and \#19/20) the particulate trace metal concentrations featured maxima in the top $100 \mathrm{~m}$ of the water column (Figs. 2 and 5). At site \#19/20, ca. $100 \mathrm{~km}$ away from the coast with a water depth of $1741 \mathrm{~m}$, the $\mathrm{PFe}$ concentration at $20 \mathrm{~m}$ depth was $97 \mathrm{nmol} \mathrm{L}^{-1}$, similar to $\mathrm{LP}_{\mathrm{Un}} \mathrm{Fe}$ (Fig. 5). The elemental ratio $\mathrm{PFe} / \mathrm{PAl}$ of these samples (e.g. 1.01 for site \#19/20, $20 \mathrm{~m}$ depth) was close to the average ratio $(\mathrm{PFe} / \mathrm{PAl}=1.25)$, indicating that lithogenic and authigenic Fe dominated the suspended particulate pool in these surface waters.

The surface water maxima of trace metals could have two supply routes: (1) lateral transport of waters containing lithogenic and authigenic particles from shallow island shelf sediments, and (2) transport of glacial particles following melt processes. The reduced salinities ( $\sim 33.3$ PSU) recorded in surface waters in Cumberland Bay and $\sim 50 \mathrm{~km}$ offshore of South Georgia ( 33.8) (Figs. 6c and S2) provide an indication of glacial outflow, melting of icebergs, and run-off of meltwater streams. Enhanced $\mathrm{LP}_{\mathrm{Un}} \mathrm{Fe}$ concentrations of $2.2 \mu \mathrm{mol} \mathrm{L}^{-1}$ in low-salinity surface waters inside Cumberland Bay are indicative of a meltwater source $\left(\mathrm{LP}_{\mathrm{Un}}\right.$ concentration used as only water samples from the tow fish available). The $\mathrm{LP}_{\mathrm{Un}} \mathrm{Fe}$ concentration decreased strongly with increasing distance from the coast and exhibited an abrupt reduction to $1-5 \mathrm{nmol} \mathrm{Fe} \mathrm{L}^{-1}$ at the shelf edge $\sim 100 \mathrm{~km}$ offshore. A similar distribution pattern was observed for $\mathrm{LP}_{\mathrm{Un}} \mathrm{Mn}$ (Fig. 6d) and $\mathrm{LP}_{\mathrm{Un}} \mathrm{Al}$ (not shown), for cruises JR247 and JR274. Glacial melt has been reported as an important source of particulate material in the vicinity of the Antarctic Peninsula (de Jong et al., 2012). For example, Gerringa et al. (2012) documented elevated total dissolvable Fe concentration of up to $106 \mathrm{nmol} \mathrm{L}^{-1}$ near the Pine Island Glacier in the Amundsen Sea, and Raiswell et al. (2008) estimated that per year $1.6 \mathrm{Gmol}$ of nanoparticulate $\mathrm{Fe}$, associated with lithogenic particles, is delivered to the Southern Ocean by melting ice.

Locally elevated particulate metal concentrations in surface waters may also be related to production of faecal pellets by swarms of Antarctic krill (Schmidt et al., 2016). High 
Table 2. SAPS samples: the particulate $\mathrm{Fe}(\mathrm{PFe}), \mathrm{Mn}(\mathrm{PMn})$, and $\mathrm{Al}(\mathrm{PAl})$ concentrations in the top $150 \mathrm{~m}$ of the water column at the 14 sites visited during JR247. The particulate fraction, $P$, is the sum of leachable $(L)$ and refractory $(R)$ fractions. Because of low concentrations, the leachable fraction is indicated in percent of the $P$ fraction. Additional information covers sampling date, site (station) ID, event number, latitude and longitude, and water column depth. (Depths marked by * indicate that the polycarbonate filter was corrupted after retrieving the SAPS.)

\begin{tabular}{|c|c|c|c|c|c|c|c|c|}
\hline \multirow[t]{2}{*}{ Date } & \multirow{2}{*}{$\begin{array}{l}\text { Site ID } \\
\text { lat., long. }\end{array}$} & \multirow{2}{*}{$\begin{array}{r}\text { Depth } \\
(\mathrm{m})\end{array}$} & \multicolumn{3}{|c|}{ Particulate $\left(\mathrm{nmol} \mathrm{L}^{-1}\right)$} & \multicolumn{3}{|c|}{ Leachable $(\%$ of $P$ ) } \\
\hline & & & $\mathrm{PFe}$ & PMn & PAl & $\mathrm{LFe}$ & LMn & LAl \\
\hline \multirow{3}{*}{$25 / 12 / 2010$} & $\# 1 / 2(\mathrm{E} 22)$ & 20 & 5.17 & 0.08 & 4.82 & 0.37 & 2.39 & 1.65 \\
\hline & $53.70^{\circ} \mathrm{S}, 38.21^{\circ} \mathrm{W}$ & $50 *$ & 9.12 & 0.14 & 7.91 & 0.27 & 2.61 & 1.47 \\
\hline & (322 m) & $150^{*}$ & 76.61 & 1.09 & 66.91 & 6.26 & 2.74 & 4.65 \\
\hline \multirow[t]{3}{*}{$26 / 12 / 2010$} & \#3 (E31) & 20 & 6.62 & 0.09 & 6.64 & 0.02 & 3.30 & 0.79 \\
\hline & $53.85^{\circ} \mathrm{S}, 39.14^{\circ} \mathrm{W}$ & 50 & 267.48 & 3.85 & 162.59 & 1.48 & 0.79 & 0.65 \\
\hline & $(287 \mathrm{~m})$ & 150 & 4.36 & 0.06 & 4.26 & 0.07 & 1.55 & 1.93 \\
\hline \multirow[t]{3}{*}{$31 / 12 / 2010$} & \#4/5 (E72) & 20 & 8.52 & 0.12 & 7.99 & 0.51 & 1.68 & 2.62 \\
\hline & $53.49^{\circ} \mathrm{S}, 37.71^{\circ} \mathrm{W}$ & 50 & 15.15 & 0.23 & 12.96 & 0.56 & 2.44 & 2.74 \\
\hline & $(1917 \mathrm{~m})$ & 150 & 2.33 & 0.03 & 2.15 & 0.65 & 1.78 & 2.42 \\
\hline \multirow[t]{3}{*}{ 02/01/2011 } & \#6 (E80) & 20 & 85.74 & 1.11 & 59.05 & 1.60 & 2.28 & 4.50 \\
\hline & $53.99^{\circ} \mathrm{S}, 36.37^{\circ} \mathrm{W}$ & 50 & 17.76 & 0.24 & 8.87 & - & - & - \\
\hline & $(208 \mathrm{~m})$ & 150 & 137.39 & 2.02 & 98.54 & 3.46 & 0.91 & 2.81 \\
\hline \multirow[t]{3}{*}{ 03/01/2011 } & \#7/8 (E88) & 20 & 1.95 & 0.02 & 0.87 & 0.13 & 2.97 & 4.99 \\
\hline & $54.10^{\circ} \mathrm{S}, 35.46^{\circ} \mathrm{W}$ & 50 & 1.67 & 0.02 & 0.92 & 0.08 & 4.35 & 4.24 \\
\hline & $(330 \mathrm{~m})$ & 150 & 1.23 & 0.02 & 0.71 & 0.19 & 2.11 & 5.13 \\
\hline \multirow[t]{3}{*}{ 04/01/2011 } & \#9/10 (E96) & 20 & 20.91 & 0.08 & 15.74 & 0.56 & 5.01 & 3.24 \\
\hline & $54.26^{\circ} \mathrm{S}, 35.35^{\circ} \mathrm{W}$ & 50 & 19.16 & 0.27 & 15.58 & 0.45 & 1.22 & 2.51 \\
\hline & $(263 \mathrm{~m})$ & 150 & 54.06 & 0.77 & 48.10 & 1.08 & 1.65 & 2.08 \\
\hline \multirow[t]{3}{*}{ 05/01/2011 } & $\# 11 / 12$ (E100) & $20^{*}$ & 1.49 & 0.01 & 0.86 & 0.18 & 4.42 & 2.92 \\
\hline & $54.62^{\circ} \mathrm{S}, 34.81^{\circ} \mathrm{W}$ & 50 & 0.87 & 0.01 & 0.60 & 0.27 & 6.63 & 4.20 \\
\hline & $(747 \mathrm{~m})$ & 150 & 1.76 & 0.03 & 1.08 & 0.37 & 4.38 & 3.33 \\
\hline \multirow[t]{3}{*}{ 06/01/2011 } & \#13 (E106) & 20 & 2.75 & 0.03 & 1.78 & 0.63 & 3.13 & 4.29 \\
\hline & $54.53^{\circ} \mathrm{S}, 35.27^{\circ} \mathrm{W}$ & 50 & 4.11 & 0.05 & 3.07 & 0.44 & 2.04 & 2.76 \\
\hline & $(133 \mathrm{~m})$ & 100 & 10.28 & 0.15 & 7.62 & 0.46 & 1.70 & 2.54 \\
\hline \multirow[t]{3}{*}{ 07/01/2011 } & \#14 (E114) & 20 & 2.80 & 0.04 & 1.84 & 0.07 & 1.58 & 3.29 \\
\hline & $54.56^{\circ} \mathrm{S}, 35.59^{\circ} \mathrm{W}$ & 50 & 1.41 & 0.02 & 0.97 & 0.10 & 2.57 & 3.92 \\
\hline & $(263 \mathrm{~m})$ & 150 & 31.34 & 0.46 & 26.92 & 0.72 & 1.57 & 2.28 \\
\hline \multirow[t]{3}{*}{ 08/01/2011 } & $\# 15 / 16(\mathrm{E} 120)$ & 20 & 24.54 & 0.37 & 22.91 & 0.85 & 3.95 & 1.88 \\
\hline & $53.62^{\circ} \mathrm{S}, 36.34^{\circ} \mathrm{W}$ & 50 & 27.72 & 0.40 & 23.23 & 0.43 & 3.65 & 1.36 \\
\hline & $(852 \mathrm{~m})$ & 150 & 4.74 & 0.07 & 3.94 & 0.90 & 4.31 & 1.06 \\
\hline \multirow[t]{3}{*}{$10 / 01 / 2011$} & \#17 (E134) & 20 & 10.43 & 0.14 & 8.09 & 0.34 & 1.66 & 2.41 \\
\hline & $53.90^{\circ} \mathrm{S}, 36.57^{\circ} \mathrm{W}$ & 50 & 43.04 & 0.60 & 38.79 & 1.34 & 1.07 & 1.67 \\
\hline & $(209 \mathrm{~m})$ & 150 & 207.48 & 3.10 & 194.88 & 1.72 & 0.82 & 1.50 \\
\hline \multirow[t]{3}{*}{$11 / 01 / 2011$} & \#18 (E139) & 20 & 95.52 & 1.32 & 88.39 & 1.39 & 1.82 & 1.93 \\
\hline & $54.10^{\circ} \mathrm{S}, 36.25^{\circ} \mathrm{W}$ & 50 & 37.43 & 0.52 & 35.33 & 1.16 & 1.29 & 1.85 \\
\hline & $(276 \mathrm{~m})$ & 150 & 28.00 & 0.41 & 23.60 & 1.26 & 2.35 & 2.27 \\
\hline \multirow[t]{3}{*}{$12 / 01 / 2011$} & \#19/20 (E142) & 20 & 97.60 & 1.52 & 97.10 & 0.16 & 1.66 & 0.33 \\
\hline & $53.54^{\circ} \mathrm{S}, 38.11^{\circ} \mathrm{W}$ & 50 & 90.96 & 1.42 & 92.89 & 0.39 & 1.98 & 0.80 \\
\hline & $(1741 \mathrm{~m})$ & 150 & 7.41 & 0.12 & 6.37 & 0.74 & 8.25 & 2.75 \\
\hline \multirow[t]{3}{*}{ 13/01/2011 } & \#21 (E152) & 20 & 50.75 & 0.85 & 52.78 & 0.06 & 2.99 & 0.12 \\
\hline & $53.75^{\circ} \mathrm{S}, 38.98^{\circ} \mathrm{W}$ & 50 & 59.59 & 0.93 & 59.98 & 0.05 & 2.15 & 0.09 \\
\hline & $(269 \mathrm{~m})$ & 150 & 153.48 & 2.34 & 89.63 & 3.14 & 1.10 & 2.94 \\
\hline
\end{tabular}



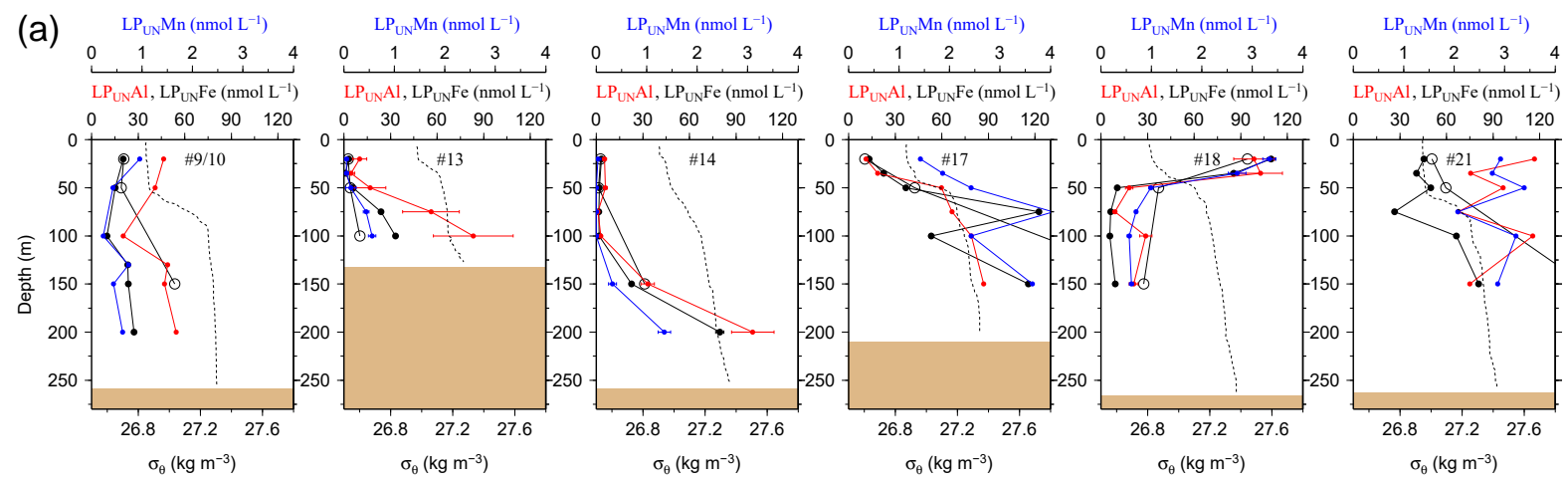

(b)
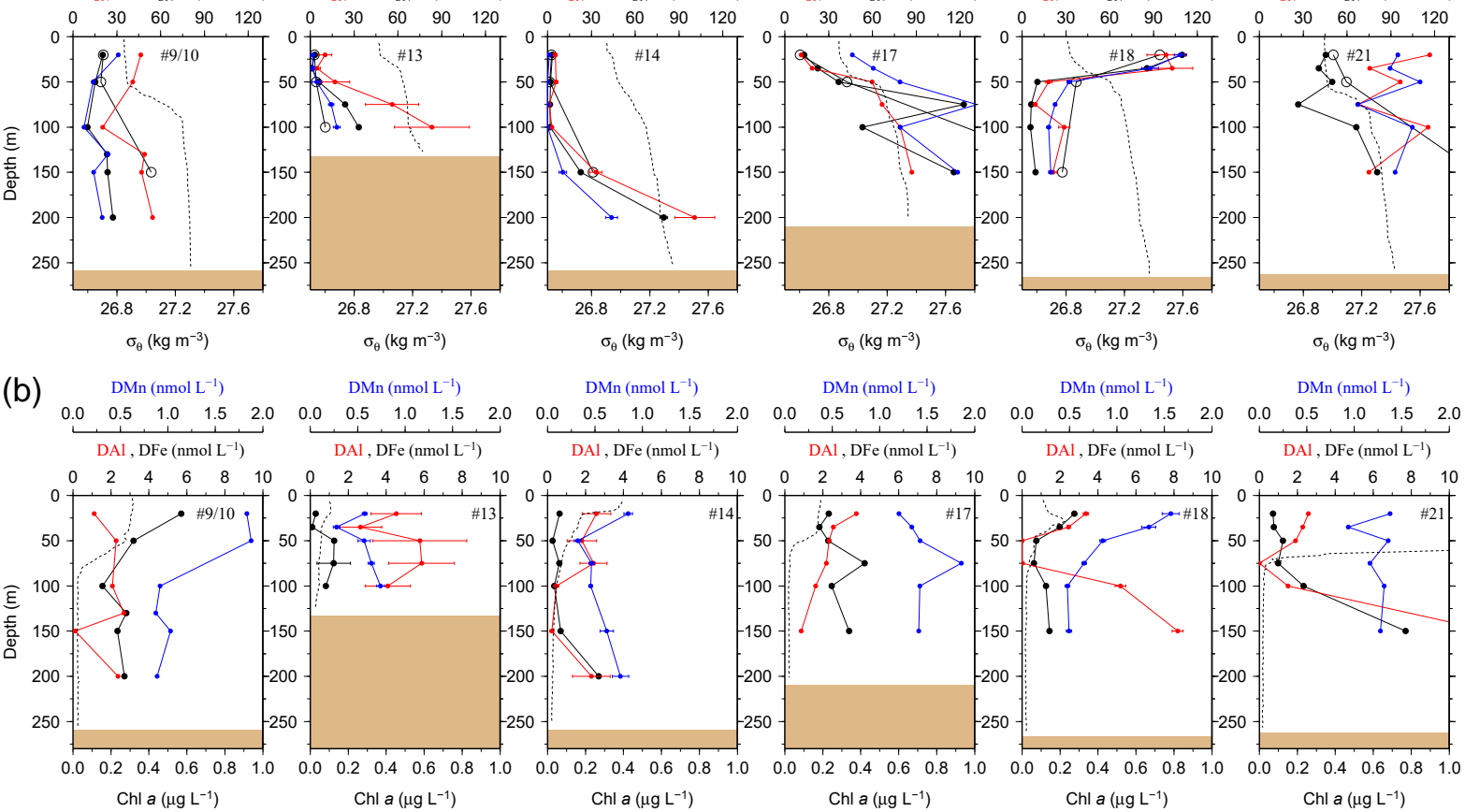

Figure 2. (a) OTE seawater samples: distribution of leachable particulate iron ( $\mathrm{LP}_{\mathrm{Un}} \mathrm{Fe}$ in black), manganese ( $\mathrm{LP}_{\mathrm{Un}} \mathrm{Mn}$ in blue), and aluminium ( $\mathrm{LP}_{\mathrm{Un}} \mathrm{Al}$ in red) concentrations in the water column of stations located on the island shelf (125-270 m water depth). SAPS samples: the particulate $\mathrm{Fe}(\mathrm{PFe})$ fraction retrieved by SAPS is illustrated with open black circles and corresponds to the same axis as $\mathrm{LP}_{\mathrm{Un}} \mathrm{Fe}$. Concentrations above $120 \mathrm{nmol} \mathrm{L}^{-1}$ are listed in Tables 1 and 2. Error bars represent the standard deviation of the analysis. Density $\left(\sigma_{\theta}\right)$ in kilograms per cubic metre is illustrated by the black dashed line. (b) OTE seawater samples: dissolved iron (DFe), manganese (DMn), and aluminium (DAl) are represented by the same colour code as above. Dashed lines illustrate Chlorophyll $a(\mathrm{Chl} a)$ content of the water column recorded by the CTD fluorometer.

Table 3. The different elemental ratios of the Earth's crust, sediment, suspended particles (SAPS), faecal pellets, and biogenic particles (average phytoplankton species).

\begin{tabular}{lrrrl}
\hline Particle & $\begin{array}{r}\mathrm{Fe} / \mathrm{Mn} \\
\left(\mathrm{mol} \mathrm{mol}^{-1}\right)\end{array}$ & $\begin{array}{r}\mathrm{Fe} / \mathrm{Al} \\
\left(\mathrm{mol} \mathrm{mol}^{-1}\right)\end{array}$ & $\begin{array}{r}\mathrm{Mn} / \mathrm{Al} \\
\left(\mathrm{mol} \mathrm{mol}^{-1}\right)\end{array}$ & Source \\
\hline Crust & 58.00 & 0.20 & 0.0035 & a \\
Sediment & 51.50 & 0.34 & 0.0066 & This study \\
Suspended part. (SAPS) & 68.00 & 1.25 & 0.0171 & This study \\
Faecal pellets & 70.65 & 0.48 & 0.0069 & This study \\
Phytoplankton & 1.70 & - & - & b \\
\hline
\end{tabular}

${ }^{\mathrm{a}}$ Wedepohl (1995). ${ }^{\mathrm{b}}$ Ho et al. (2003).

abundances of Antarctic krill were estimated from acoustic backscattering observations (Fielding et al., 2014), and large numbers of faecal pellets were observed on the SAPS filters during cruise JR247. The stomach content of Antarctic krill contained up to $90 \%$ sediment particles by volume, an observation that was attributed to filter feeding by these organisms on phytoplankton and seabed detritus, with incidental ingestion of deep-ocean sediments (Schmidt et al., 2011) and glacial flour (Schmidt et al., 2016). Krill thus take up lithogenic (sediment) particles and transfer these into the surface ocean through the egestion of faecal pellets (Schmidt et al., 2016). The trace metal contents of krill faecal pellets collected during on-board incubation experiments during JR247 ranged from 0.88 to $67.14 \mu \mathrm{g} \mathrm{Fe} \mathrm{mg}^{-1}$ dry weight $(n=27)$ (Table 5) (Schmidt et al. 2016). The molar ratios of the faecal pellets $(\mathrm{PFe} / \mathrm{PAl}=0.48 \pm 0.07$ and $\mathrm{PMn} / \mathrm{PAl}=$ $0.0069 \pm 0.001)$ were similar to those for sediment particles $(\mathrm{SFe} / \mathrm{SAl}=0.34 \pm 0.02$ and $\mathrm{SMn} / \mathrm{SAl}=0.0066 \pm 0.001$; 
Table 4. Sediment core samples: particulate iron (SFe), aluminum (SAl), and manganese (SMn) concentrations in shelf sediments collected during JC055 in January and February 2011. Pore water data retrieved additionally from these three cores are listed for Fe (Fepw) and Mn (MnPw). Additional information are event number (MC...), latitude and longitude, and water column depth.

\begin{tabular}{|c|c|c|c|c|c|c|}
\hline $\begin{array}{l}\text { Station ID } \\
\text { lat., long. }\end{array}$ & $\begin{array}{r}\text { Depth } \\
(\mathrm{cm})\end{array}$ & $\begin{array}{r}\mathrm{SFe} \\
\left(\mathrm{mol} \mathrm{kg}^{-1}\right)\end{array}$ & $\begin{array}{r}\text { SAl } \\
\left(\mathrm{mol} \mathrm{kg}^{-1}\right)\end{array}$ & $\begin{array}{r}\mathrm{SMn} \\
\left(\mathrm{mmol} \mathrm{kg}^{-1}\right)\end{array}$ & $\begin{array}{r}\text { Fe }_{\mathrm{PW}} \\
\left(\mu \mathrm{mol} \mathrm{kg}{ }^{-1}\right)\end{array}$ & $\begin{array}{r}\mathrm{Mn}_{\mathrm{PW}} \\
\left(\mu \mathrm{mol} \mathrm{kg}{ }^{-1}\right)\end{array}$ \\
\hline \#S1 (MC33) & 0.5 & 0.58 & 1.77 & 11.56 & 3.01 & 2.29 \\
\hline $54.16^{\circ} \mathrm{S}, 37.98^{\circ} \mathrm{W}$ & 1.5 & 0.61 & 1.74 & 11.52 & 17.47 & 0.84 \\
\hline \multirow[t]{7}{*}{$(257 \mathrm{~m})$} & 2.5 & 0.59 & 1.77 & 11.78 & 110.90 & 0.28 \\
\hline & 3.5 & 0.6 & 1.86 & 12.05 & 106.24 & 0.53 \\
\hline & 4.5 & 0.58 & 1.72 & 11.82 & 94.09 & 0.34 \\
\hline & 5.5 & 0.59 & 1.86 & 12.04 & 82.79 & 0.27 \\
\hline & 9 & 0.56 & 1.72 & 11.19 & 32.98 & 0.00 \\
\hline & 15 & 0.55 & 1.74 & 11.15 & 2.44 & 0.06 \\
\hline & 25 & 0.53 & 1.6 & 10.81 & 0.80 & 0.16 \\
\hline \#S2 (MC34) & 0.5 & 0.64 & 1.77 & 11.42 & 1.53 & 0.87 \\
\hline $54.16^{\circ} \mathrm{S}, 37.94^{\circ} \mathrm{W}$ & 1.5 & 0.6 & 1.79 & 11.73 & - & - \\
\hline \multirow[t]{5}{*}{$(247 \mathrm{~m})$} & 2.5 & 0.58 & 1.76 & 11.81 & 0.97 & 0.24 \\
\hline & 6.5 & 0.59 & 1.83 & 12.23 & 11.19 & 0.26 \\
\hline & 10.5 & 0.58 & 1.8 & 11.78 & 14.28 & 0.25 \\
\hline & 14.5 & 0.54 & 1.6 & 10.83 & 3.59 & 0.33 \\
\hline & 16.5 & 0.56 & 1.72 & 11.22 & 2.27 & 0.31 \\
\hline \#S3 (MC35) & 0.5 & 0.61 & 1.67 & 11.42 & 1.46 & 0.43 \\
\hline $54.15^{\circ} \mathrm{S}, 37.97^{\circ} \mathrm{W}$ & 1.5 & 0.59 & 1.76 & 11.7 & 28.94 & 0.35 \\
\hline \multirow[t]{8}{*}{$(254 \mathrm{~m})$} & 2.5 & 0.58 & 1.76 & 11.7 & 91.52 & 0.37 \\
\hline & 3.5 & 0.59 & 1.81 & 12.03 & 40.16 & 0.44 \\
\hline & 5.5 & 0.57 & 1.78 & 11.58 & 49.37 & 0.56 \\
\hline & 8.5 & 0.59 & 1.82 & 11.65 & 67.92 & 0.52 \\
\hline & 17 & 0.54 & 1.69 & 10.8 & 3.87 & 0.34 \\
\hline & 19 & 0.55 & 1.67 & 10.86 & 1.82 & 0.12 \\
\hline & 25 & 0.55 & 1.77 & 11.19 & 2.73 & 0.36 \\
\hline & 29 & 0.56 & 1.79 & 11.19 & 5.64 & 0.16 \\
\hline
\end{tabular}

Tables 1, 2, 3, and 4), indicating that Fe in krill faecal pellets was predominately associated with lithogenic (sediments) and/or glacial flour particles, as also reported by Schmidt et al. (2016). In contrast, the molar ratio of faecal pellets $(\mathrm{PFe} / \mathrm{PMn}=70.65 \pm 8.22)$ was higher than that of sediments $(\mathrm{SFe} / \mathrm{SMn}=51.5 \pm 2.4)$ but just slightly higher than that of suspended SAPS particles $(\mathrm{PFe} / \mathrm{PAl}=68.0 \pm 0.6)$. The observed variability in the PFe / PAl and PFe / PMn ratio in the various particle pools is therefore a consequence of different amounts of lithogenic and authigenic particles.

\subsection{Supply routes of dissolved Fe, Mn, and Al}

Concentrations of DFe, DMn, and DAl in the water column showed strong variations and ranged from $\sim 0.1$ to $25.9,0.3$ to 19.6 , and 0.1 to $18.4 \mathrm{nmol} \mathrm{L}^{-1}$, respectively (Figs. 2, 5 and 7), with highest values in the surface waters in Cumberland Bay and lowest beyond the shelf break (Fig. 6). Dissolved Fe concentrations from this study are in agreement with reported DFe near the Antarctic Peninsula (0.6$14.6 \mathrm{nmol} \mathrm{L}^{-1}$; de Jong et al., 2012) and Crozet Islands (0.1$2.5 \mathrm{nmol} \mathrm{L}^{-1}$; Planquette et al., 2007). Sources and sinks of dissolved trace metals, and their distribution in the water column are discussed in the following sections.

\subsubsection{Supply from sediment pore waters}

Elevated pore water concentrations of $\mathrm{Fe}$ and $\mathrm{Mn}$ (Fepw and MnPw) were observed in sediments from the southern shelf sites at water depths of around $250 \mathrm{~m}$ and ranged from 0.5 to $110 \mu \mathrm{mol} \mathrm{L}{ }^{-1}$ for Fe and 0.1 to $2 \mu \mathrm{mol} \mathrm{L}^{-1}$ for Mn (Fig. 7 and Table S2 in the Supplement). The down-core distributions of $\mathrm{Fe}_{\mathrm{PW}}$ and $\mathrm{Mn}_{\mathrm{PW}}$ were consistent with microbial dissimilatory $\mathrm{Mn}$ and Fe reduction during organic matter oxidation (Canfield and Thamdrup, 2009), and thus concentrations were elevated at defined depth horizons controlled by their redox potential (Eh) (Bonneville et al., 2009; Raiswell and Canfield, 2012). The Fepw and MnPw concentrations near the sediment-seawater interface were used to calculate fluxes of $\mathrm{Fe}$ and $\mathrm{Mn}$ to bottom waters following diffusion of reduced $\mathrm{Fe}$ and $\mathrm{Mn}$ species across an oxygenated layer in surface sediments. These calculations were performed following Boudreau and Scott (1978) and Homoky et al. (2012), and are described in detailed in the Sect. S3 and Table S1. We 
Table 5. Krill faecal pellets: particulate $(P)$ and leachable $(L)$ concentrations for Fe, Mn, and Al determined for the 27 individual krill faecal pellet samples collected during nine krill incubation experiments on board RRS James Clark Ross (JR247). The particulate fraction, $P$, is the sum of leachable $(L)$ and refractory $(R)$ fractions. Because of low concentrations, the leachable fraction is indicated in percent of the $P$ fraction.

\begin{tabular}{|c|c|c|c|c|c|c|c|}
\hline Sample no. & $\begin{array}{r}\text { Pellet weight } \\
(\mathrm{mg})\end{array}$ & $\begin{array}{r}\mathrm{PFe} \\
\left(\mu \mathrm{g} \mathrm{mg}^{-1}\right)\end{array}$ & $\begin{array}{r}\text { PAl } \\
\left(\mu \mathrm{g} \mathrm{m}^{-1}\right)\end{array}$ & $\begin{array}{r}\text { PMn } \\
\left(\mathrm{ng} \mathrm{mg}^{-1}\right)\end{array}$ & $\begin{array}{r}\mathrm{LFe} \\
(\%)\end{array}$ & $\begin{array}{l}\text { LAl } \\
(\%)\end{array}$ & $\begin{array}{r}\mathrm{LMn} \\
(\%)\end{array}$ \\
\hline 1 & 4.87 & 0.88 & 1.06 & 12.5 & 6.33 & 8.83 & 13.24 \\
\hline 2 & 2.18 & 1.33 & 1.68 & 16.7 & 3.02 & 8.81 & 8.22 \\
\hline 3 & 4.26 & 1.07 & 1.90 & 17.8 & 5.37 & 3.27 & 11.81 \\
\hline 4 & 1.91 & 5.19 & 5.53 & 76.1 & 2.15 & 1.95 & 5.68 \\
\hline 5 & 1.41 & 2.70 & 2.84 & 39.1 & 2.46 & 1.59 & 3.54 \\
\hline 7 & 7.80 & 67.1 & 64.2 & 998.3 & 2.93 & 2.21 & 3.25 \\
\hline 8 & 0.99 & 2.71 & 2.42 & 35.0 & 3.76 & 4.59 & 5.99 \\
\hline 10 & 1.48 & 6.42 & 4.89 & 71.6 & 0.29 & 4.83 & 0.91 \\
\hline 13 & 2.79 & 4.13 & 3.11 & 50.3 & 0.36 & 5.07 & 1.53 \\
\hline 15 & 0.77 & 37.3 & 38.1 & 531.1 & 2.03 & 2.80 & 6.21 \\
\hline 16 & 1.21 & 6.35 & 6.22 & 81.2 & 1.24 & 7.47 & 3.13 \\
\hline 18 & 12.27 & 40.0 & 36.6 & 582.5 & 3.95 & 2.07 & 4.29 \\
\hline 19 & 2.19 & 11.2 & 9.49 & 146.9 & 0.15 & 2.03 & 1.07 \\
\hline 22 & 2.43 & 48.1 & 49.7 & 721.5 & 0.81 & 2.32 & 0.98 \\
\hline 40 & 3.35 & 22.8 & 22.0 & 337.4 & 5.51 & 3.21 & 5.50 \\
\hline 41 & 8.55 & 6.91 & 7.14 & 103.1 & 1.11 & 1.88 & 4.31 \\
\hline 42 & 3.5 & 25.7 & 24.8 & 376.2 & 5.09 & 2.98 & 5.29 \\
\hline 45 & 0.40 & 3.96 & 4.43 & 43.3 & 1.27 & 13.90 & 1.46 \\
\hline 47 & 7.65 & 3.63 & 3.92 & 52.7 & 0.34 & 0.68 & 3.65 \\
\hline 48 & 0.63 & 3.06 & 3.21 & 34.1 & 0.05 & 4.22 & 0.76 \\
\hline 49 & 4.42 & 29.6 & 28.5 & 438.4 & 1.65 & 2.93 & 1.95 \\
\hline 50 & 7.46 & 2.31 & 2.37 & 34.6 & 0.36 & 0.51 & 2.78 \\
\hline 51 & 5.18 & 28.0 & 27.1 & 431.3 & 1.85 & 2.60 & 2.01 \\
\hline 62 & 1.20 & 4.63 & 4.68 & 68.0 & 0.31 & 1.78 & 0.47 \\
\hline 68 & 2.25 & 44.0 & 40.2 & 667.4 & 4.84 & 1.95 & 4.77 \\
\hline 69 & 1.66 & 43.6 & 44.8 & 663.7 & 5.66 & 2.13 & 5.46 \\
\hline 71 & 3.47 & 35.3 & 36.4 & 557.7 & 1.50 & 1.99 & 1.76 \\
\hline
\end{tabular}

are aware that our calculated fluxes represent minimum estimates of pore water efflux, which under natural conditions is supplemented by advection due to bioirrigation, bioturbation, and bottom water currents (Homoky et al., 2016). In addition, sediment cores were collected on the southern shelf, while seawater and particulate samples were collected on the northern shelf side. The benthic Fe fluxes for the southern shelf may be lower than those on the northern shelf, as an elevated primary productivity and enhanced particle export on the northern side will result in enhanced bacterial respiration, which reduces Eh and promotes the dissolution of Fe oxides with subsequent release of Fe into bottom waters.

Notwithstanding the above issues, we calculated substantial benthic fluxes from sediment pore waters to bottom waters on the southern shelf for $F_{\text {PW }}$ of $<0.1$ to $44.4 \mu \mathrm{mol} \mathrm{m}{ }^{-2} \mathrm{~d}^{-1}$ and MnPw of 0.6 to $4.1 \mu \mathrm{mol} \mathrm{m}{ }^{-2} \mathrm{~d}^{-1}$. The upper flux values for $\mathrm{Fe}$ are comparable to those reported for dysoxic and river-dominated continental margins (3.5$55 \mu \mathrm{mol} \mathrm{m}{ }^{-2} \mathrm{~d}^{-1}$; Homoky et al., 2012), seasonal maxima of temperate and oxic shelf seas $\left(23-31 \mu \mathrm{mol} \mathrm{m}{ }^{-2} \mathrm{~d}^{-1}\right.$; Klar et al., 2017), and shelf sediments off the Antarctic Peninsula (1.3-15.5 $\mathrm{mmol} \mathrm{m}^{-2} \mathrm{~d}^{-1}$; de Jong et al., 2012). The Mn fluxes were relatively low for shelf environments, with for example fluxes of $70-4450 \mu \mathrm{mol} \mathrm{m}{ }^{-2} \mathrm{~d}^{-1}$ reported for Baltic and Black Sea sediments (Pakhomova et al., 2007). The Fe pore water fluxes from the South Georgia shelf sediments, which extend over an area of ca. $40000 \mathrm{~km}^{2}$, indicate that these may serve as an important year-round source to overlying waters, totalling 4 to $1728 \mathrm{kmolDFe} \mathrm{d}^{-1}$ and 25 to $164 \mathrm{kmol} \mathrm{DMn} \mathrm{d}^{-1}$.

Benthic release of trace-metal-enriched pore waters shaped the distributions of dissolved trace metals in bottom waters on the shelf. Concentrations of DFe, DMn, and DAl were enhanced at isopycnals $>27.05 \mathrm{~kg} \mathrm{~m}^{-3}$ (e.g. DFe up to $7.70 \mathrm{nmol} \mathrm{L}^{-1}$ at site $\# 21$, Table 1) compared to surface waters (e.g. DFe as low as $0.30 \mathrm{nmol} \mathrm{L}^{-1}$ at site \#13, Table 1; Figs. 2 and 7). Trace-metal-enriched bottom waters were also observed at sites \#13, \#14, \#17, and \#18 (Fig. 2). The molar DFe / DMn ratios in oxygenated bottom waters varied between 1.1 and 3.5 and were thus similar to pore 

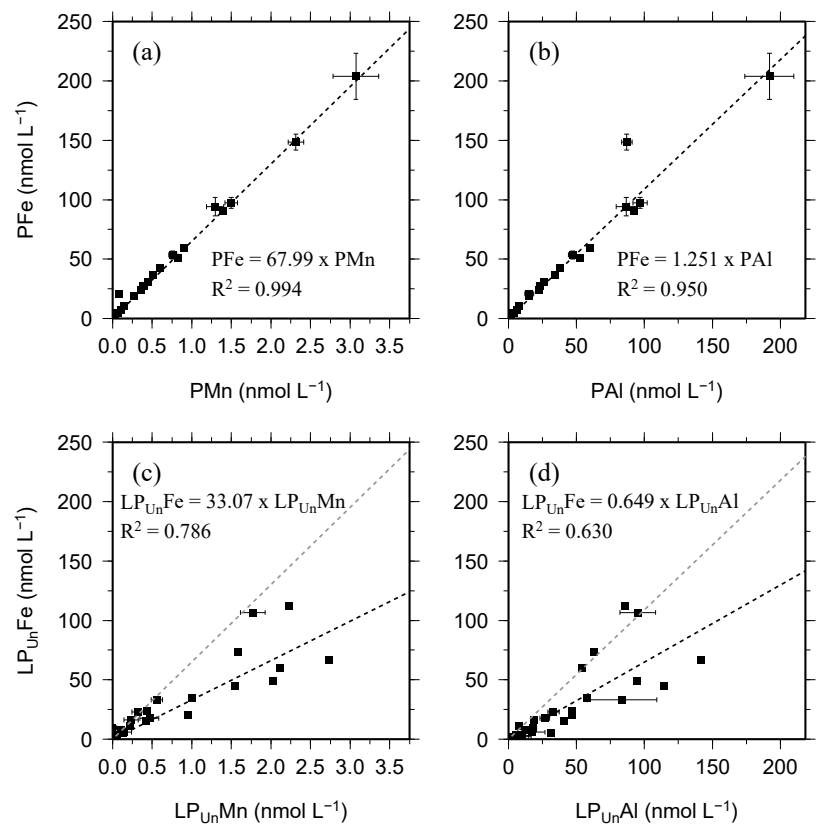

Figure 3. Relationship of the entire data set for the particulate fraction of $\mathrm{Fe}, \mathrm{Mn}$, and $\mathrm{Al}$ in particulates $(P)$ retrieved using SAPS (a, b) and the leachable particulate fraction $\left(\mathrm{LP}_{\mathrm{Un}}\right)$ estimated from unfiltered and dissolved seawater samples collected using OTE bottles (c, d). Error bars represent the standard deviation of the analysis. The linear regression of each relationship is illustrated by a dashed black line, the formula, and the $R^{2}$. The grey dashed line in (c) and (d) represents the linear relationship of particulate trace meals $(P)$ shown in (a) and (b).

waters near the sediment-seawater interface $(0-1 \mathrm{~cm}$ depth; $\mathrm{Fe}_{\mathrm{PW}} / \mathrm{Mn}_{\mathrm{PW}}=2.2 \pm 1.0$; Fig. 7). The similar trace metal ratios suggest that $\mathrm{Fe}$ and $\mathrm{Mn}$ in enriched pore waters crossed the sediment-bottom water interface and accumulated in shelf bottom waters.

To determine the vertical DFe fluxes from near bottom to surface waters, we employed a method outlined by de Jong et al. (2012) and calculated both the advective and diffusive flux terms, which are not affected by the benthic $\mathrm{Fe}$ and Mn fluxes. We included the advective term in our calculations, because it has been shown that internal waves that cross shallow topographies and wind shear stress produce strong turbulence that facilitate Eckman upwelling (vertical advection) on the shelf (Kurapov et al., 2010; Moore, 2000; Wolanski and Delesalle, 1995). Applying literature values from the Southern Ocean for vertical diffusivity $\left(K_{Z}=1 \times\right.$ $10^{-4} \mathrm{~m}^{2} \mathrm{~s}^{-1}$; Charette et al., 2007) and advective velocity $\left(w=1.1 \times 10^{-6} \mathrm{~m} \mathrm{~s}^{-1}\right.$; de Jong et al., 2012), an average vertical DFe flux on the shelf of $0.41 \pm 0.26 \mu \mathrm{mol} \mathrm{m}^{-2} \mathrm{~d}^{-1}$ from subsurface waters into the surface mixed layer was estimated (Sect. S4). The surface mixed-layer depth was determined by a density criterion $\left(\sim 0.03 \mathrm{~kg} \mathrm{~m}^{-3}\right.$; de Boyer Montégut et al., 2004) and was located at $\sim 50 \mathrm{~m}$ depth. About $38 \%$ of the DFe flux was related to Ekman upwelling (ad- vective term) and $62 \%$ to the diffusive flux. This vertical flux is at the lower end of the calculated benthic flux from this study ( $\mathrm{Fe}_{\mathrm{PW}}<0.1$ to $44.4 \mu \mathrm{mol} \mathrm{m}{ }^{-2} \mathrm{~d}^{-1}$ ) and agrees with values reported for other Southern Ocean shelf regions near the Antarctic Peninsula (within 20-70 km from the coast: $2.7 \pm 3.4 \mu \mathrm{mol} \mathrm{m}^{-2} \mathrm{~d}^{-1}$; de Jong et al., 2012) and the Crozet Islands (only diffusive flux of $0.06 \mu \mathrm{mol} \mathrm{m}^{-2} \mathrm{~d}^{-1}$; Planquette et al., 2007).

\subsubsection{DFe supply from the leachable fraction of particles}

The analytical protocol for the analysis of SAPS-collected particulate material allows separate estimation of the refractory and leachable fractions of trace elements ( $R$ and $L$, respectively). The $R$ fraction of the suspended matter is considered to include silicates and aged oxide minerals, while the $L$ fraction represents predominantly fresh oxyhydroxides, biogenic material, and loosely bound surface-associated elements which are readily remobilized using leaching procedures (Berger et al., 2008).

Concentrations of $\mathrm{LFe}, \mathrm{LMn}$, and $\mathrm{LAl}$ in the water column showed strong variations, ranging from a few picomoles to several nanomoles per litre (Table 2). On average, $\mathrm{LFe}$ and $\mathrm{LAl}$ concentrations at $150 \mathrm{~m}$ depth $\left(\sim 1.3 \mathrm{nmol} \mathrm{LFe} \mathrm{L}^{-1}\right.$ and $\sim 0.95 \mathrm{nmol} \mathrm{LAl} \mathrm{L}^{-1}$ ) were significantly higher than at 20 and $50 \mathrm{~m}: \mathrm{LFe}=0.3 \mathrm{nmol} \mathrm{L}^{-1}$ (Student $t$ test: $t[0.95 ; 28]=$ $1.725[1.703]$ ) and $\mathrm{LAl}=0.43 \mathrm{nmol} \mathrm{L}^{-1}$ (Student $t$ test: $t[0.90 ; 28]=1.383[1.313])$. The LMn concentrations did not vary strongly and remained near constant throughout the top $150 \mathrm{~m}\left(\mathrm{LMn}=8.9 \mathrm{pmolL}^{-1}\right.$; Student $t$ test: $t[0.65 ; 28]=0.400[0.390])$. The average contribution of $L$ to the particulate pool $P(R+L)$ was low: $0.83 \pm 1.13 \%$ for $\mathrm{Fe}, 2.55 \pm 1.58 \%$ for $\mathrm{Mn}$, and $2.42 \pm 1.32 \%$ for Al (Table 2 ). A study conducted in the North Pacific near the Columbia River outflow reported considerably higher $L$ fractions (e.g. $6.6 \pm 3.0 \%$ of $\mathrm{Fe}, 78.7 \pm 14.0 \%$ of $\mathrm{Mn}, 6.3 \pm 2.0 \%$ of $\mathrm{Al}$; Berger et al., 2008), which was attributed to enhanced biogenic particle levels in the low-salinity waters of the river (Berger et al., 2008). In contrast, results from our study showed that particulate trace metals predominately had a refractory component $(R)$, indicating that $\mathrm{Fe}, \mathrm{Mn}$, and $\mathrm{Al}$ were mainly incorporated in mineral structures unaffected by a weak acid leach (e.g. aged oxyhydroxides and alumosilicates).

A weak linear relationship between $R$ and $L$ was observed for Fe $\left(R^{2}=0.57, n=41\right), \mathrm{Mn}\left(R^{2}=0.64, n=41\right)$, and $\mathrm{Al}$ $\left(R^{2}=0.63, n=41\right)$ (Figs. S3 and S4), indicating that the $L$ fraction included mainly lithogenic and authigenic (e.g. scavenged) $\mathrm{Fe}, \mathrm{Mn}$, and $\mathrm{Al}$ and that not much LFe was incorporated in biogenic particles. The scavenging of dissolved trace metals by charged particle surfaces is established (Homoky et al., 2012; Koschinsky et al., 2003), but how well Fe and other trace metals can be remobilized from marine particle surfaces and which process may modify their availabil- 

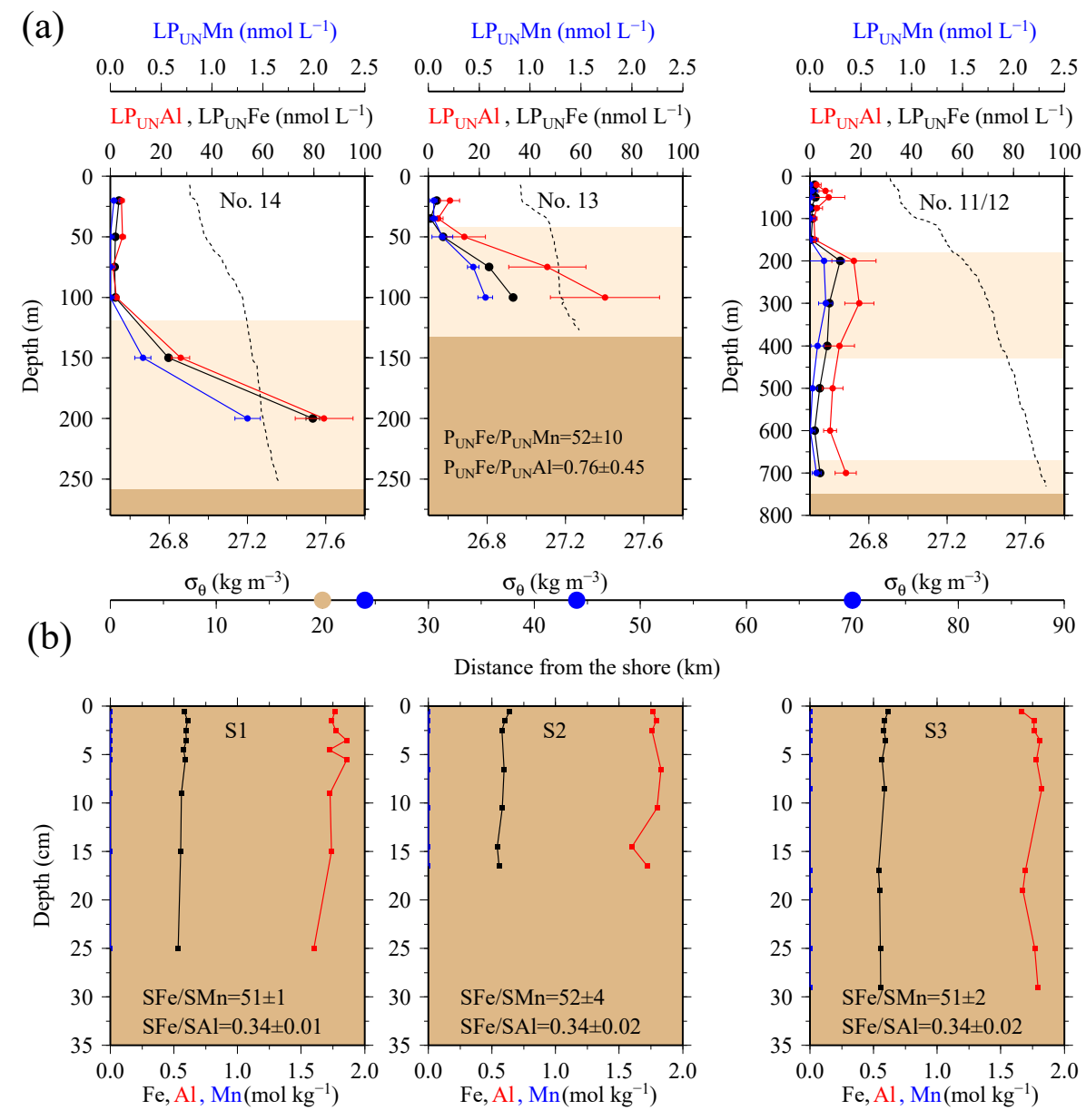

Figure 4. (a) OTE seawater samples: from left to right, concentrations of leachable particulate iron (LPUn $\mathrm{Fe})$, aluminium (LPUn $\mathrm{Al})$, and manganese (LPUn Mn) of unfiltered seawater samples for the two shelf sites (\#14,\#13) and the shelf edge site (\#11/12) (note different depth scaling). Error bars represent the standard deviation of the analysis. Water density $\left(\sigma_{\theta}\right)$ is shown by the dashed black line. Brown areas represent sediments, and pink areas the zone of resuspended sediment particles in the water column. Diagram 14 (left) contains the average $\mathrm{LP}_{\mathrm{Un}} \mathrm{Fe} / \mathrm{LP} \mathrm{Un}_{\mathrm{Al}} \mathrm{and} \mathrm{LP}_{\mathrm{Un}} \mathrm{Fe} / \mathrm{LP}_{\mathrm{Un}} \mathrm{Mn}$ ratio of particles in seawater samples collected within the pink layers. (b) sediment core samples: diagram of S1, S2, and S3 displaying the Fe, Mn, and Al content in the three sediment cores. Shown are average SFe / SAl and SFe / SMn ratios $\left(\mathrm{mol} \mathrm{mol}^{-1}\right)$ of particles from the surface layer for sites S1, S2, and S3. Dots on the distance scaling in the middle represent the distance of each water column station (blue) and sediment core (brown) station to the nearest shore.

ity over time are not yet well constrained (Achterberg et al., 2018; Fitzsimmons and Boyle, 2014; Milne et al., 2017).

For instance, scavenged $\mathrm{Fe}$ is reported to exchange with DFe in the water column of the tropical and high-latitude North Atlantic (Achterberg et al., 2018; Fitzsimmons and Boyle, 2014; Milne et al., 2017). In addition, recent work has concluded that zooplankton grazing and the production of faecal pellets remobilize DFe from lithogenic and biogenic particles (Giering et al., 2012; Schmidt et al., 2016). In contrast, freshly produced inorganic $\mathrm{Fe}(\mathrm{III})$ oxyhydroxide $\left(\mathrm{FeOOH} \times n \mathrm{H}_{2} \mathrm{O}\right)$ precipitates in seawater are accessible but are subject to chemical and structural conversions that lead to less leachable Fe with time (Yoshida et al., 2006).

\subsubsection{DFe supply from Antarctic krill}

Elevated dissolved trace metal concentrations in the top $200 \mathrm{~m}$ of the water column coincided with elevated particulate trace metal concentrations at sites \#11/12, \#15/16, \#18, and \#19/20 (Figs. 2, 5, and 7). The SAPS filters from these stations contained a high load of krill faecal pellets. To elucidate the relationship between dissolved trace metal concentrations and the local abundance of Antarctic krill and their faecal pellets, krill were caught and incubated on board the vessel as described in Schmidt et al. (2016).

Antarctic krill excretion rates of DFe were variable, relating positively to the extent of recent ingestion of diatoms. However, on average krill released $\sim 2.0 \pm$ $1.9 \mathrm{nmol} \mathrm{DFe} \mathrm{individual}^{-1} \mathrm{~d}^{-1}$ (Schmidt et al., 2016). When 
(a)
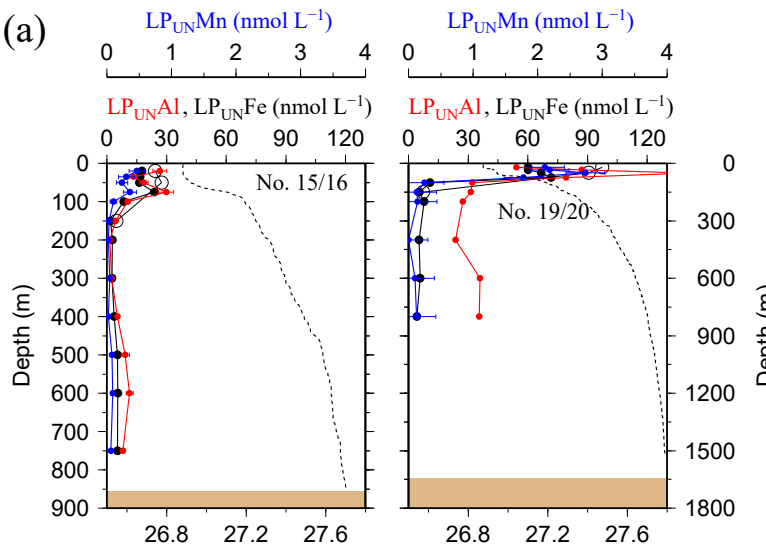

$\sigma_{\theta}\left(\mathrm{kg} \mathrm{m}^{-3}\right)$

DMn $\left(\mathrm{nmol} \mathrm{L}^{-1}\right)$

(b)
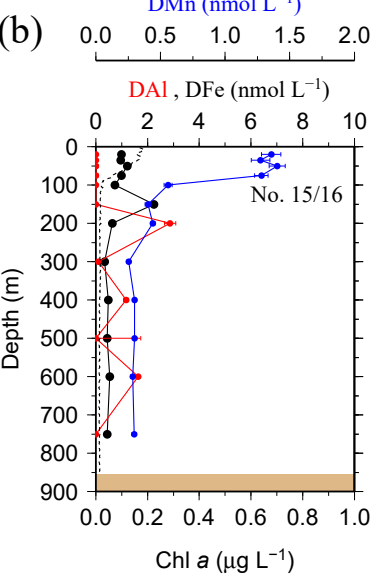

, $\mathrm{DFe}\left(\mathrm{nmol} \mathrm{L}^{-1}\right)$

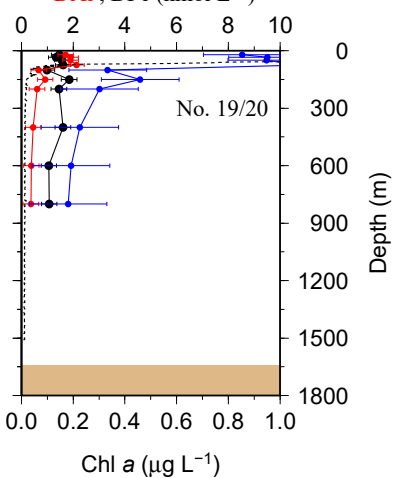

Figure 5. (a) OTE seawater samples: distribution of leachable particulate manganese $\left(\mathrm{LP}_{\mathrm{Un}} \mathrm{Mn}\right.$ in blue), iron $\left(\mathrm{LP}_{\mathrm{Un}} \mathrm{Fe}\right.$ in black), and aluminium $\left(\mathrm{LP}_{\mathrm{Un}} \mathrm{Al}\right.$ in red) concentrations in the water column of the two other stations located on the island shelf edge ( $>700 \mathrm{~m}$ water depth). SAPS samples: the particulate $\mathrm{Fe}(\mathrm{PFe})$ is illustrated by black circles and corresponds to the concentration labels of $\mathrm{LP}_{\mathrm{Un}} \mathrm{Fe}$. Error bars represent the standard deviation of the analysis. Density $\left(\sigma_{\theta}\right)$ is illustrated by the black dashed line. (b) OTE seawater samples: dissolved manganese (DMn), iron (DFe), and aluminium (DAl) are represented by the same colour code as for the upper row. Dashed line illustrates the Chl $a$ content of the water column recorded by the CTD-mounted fluorometer.

a mean krill abundance of $465 \pm 588$ individuals $\mathrm{m}^{-2}$, estimated from acoustic backscattering measurements (Fielding et al., 2014), was applied, krill excreted $1.1 \pm$ $2.2 \mu \mathrm{mol} \mathrm{DFe} \mathrm{m}{ }^{-2} \mathrm{~d}^{-1}$ into the top $300 \mathrm{~m}$ of the water column (Schmidt et al., 2016). In addition, krill produced ca. $1.8 \pm 1.6 \mathrm{mg}$ of faecal pellets per individual per day, contain-

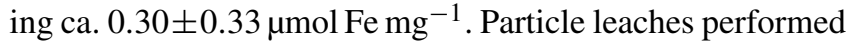
on those faecal pellet samples with $25 \%$ acetic acid showed that on average $2.5 \pm 2.1 \%\left(9.3 \pm 13.3 \mathrm{nmolFe} \mathrm{mg}^{-1}\right)$ of the total $\mathrm{Fe}$ in these pellets could be remobilized (Table 5), which would equate to a production of $14 \pm$
24 nmol LFe individual ${ }^{-1} \mathrm{~d}^{-1}$. By multiplying the mean LFe by the ambient krill density used above, we calculate a $\mathrm{LFe}$ flux of $6.5 \pm 8.2 \mu \mathrm{mol} \mathrm{m}^{-2} \mathrm{~d}^{-1}$ from the faecal pellets to the water column.

Since krill are mobile animals, questions remain over where the major part of the LFe flux occurs and what the fate of this Fe source is. The highest krill abundances have generally (but not exclusively) been recorded in the top $100 \mathrm{~m}$ layer (Fielding et al., 2014), and hence a large proportion of this LFe flux from krill is likely to occur in the upper waters. Notwithstanding our current uncertainties over the depths of origin and fate, the LFe flux from krill faecal pellets and the release of DFe were on average an order of magnitude higher than estimated vertical diffusive and advective DFe fluxes, with other grazers, such as copepods and salps, adding to the recycled-flux estimates. This illustrates the importance of zooplankton-mediated $\mathrm{Fe}$ cycling, in agreement with previous studies (Hutchins and Bruland, 1994; Sato et al., 2007).

The experimental set-up did not allow us to establish the origin of the Fe released by krill, being both "recycled" Fe from biogenic material and "new" Fe from lithogenic (and authigenic) material. However, Schmidt et al. (2016) concluded that zooplankton gut passage mobilizes lithogenic $\mathrm{Fe}$, and they showed that there are strong spatial patterns in the organic and lithogenic make-up of faecal pellets. This included an exponential decline in the quantity of lithogenic particles in krill stomachs with distance from sources of glacial flour on the northern South Georgia coast. For instance, the lithogenic content at one site on the shelf contributed $\sim 90 \%$ of stomach content volume, suggesting that a large quantity of the accessible Fe was remobilized from those inorganic particles.

\subsection{Offshore transport of trace-metal-enriched water masses}

Along a W-E transect (Fig. 1; \#14 via \# 13 to \#11/12), lateral water mass transport carried suspended particles offshore. Because of the small size of the SAPS particulate data set (two data points), we considered the $\mathrm{LP}_{\mathrm{Un}}$ fraction for this transect (Fig. 1). Indeed, elevated concentrations of the $P$ and $L P_{U n}$ metal fractions were observed in subsurface waters that had been in recent contact with the shelf. These metalenriched waters, detected at the eastern shelf edge site \#11/12 between 200 and $400 \mathrm{~m}$ water depth (Figs. 1 and 4), exhibited similar temperature and salinity signatures to shelf bottom waters. Furthermore, the elemental ratios of the $\mathrm{LP}_{\mathrm{Un}}$ fraction in these waters were similar to the particles in the surface sediments (S1, S2, and S3) and the resuspended particles in the bottom boundary layer (\#13 and \#14) on the shallow shelf (Fig. 4). A similar distribution was also found for the $P$ fractions, but limited to sites \#13 and \#14, as SAPS were not deployed below $150 \mathrm{~m}$ at the shelf edge site \#11/12.

The $\mathrm{LP}_{\mathrm{Un}} \mathrm{Fe}$ concentration decreased offshore with distance from the island: from site $\# 14$ at $200 \mathrm{~m}$ depth 


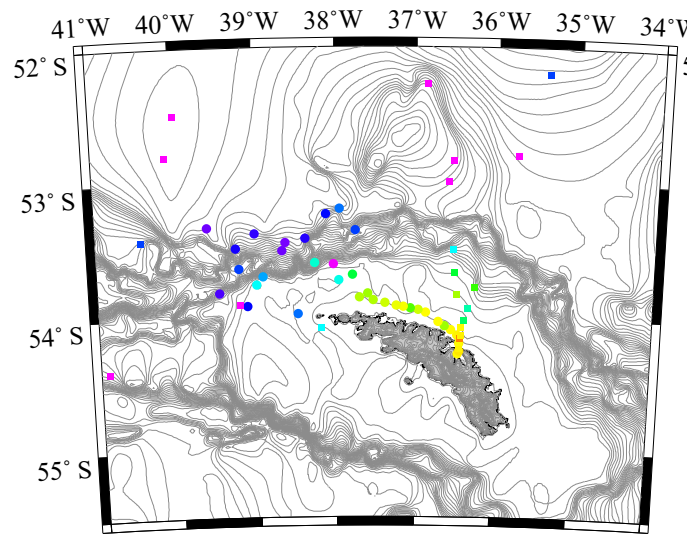

(a)

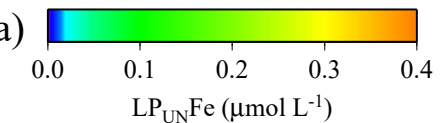

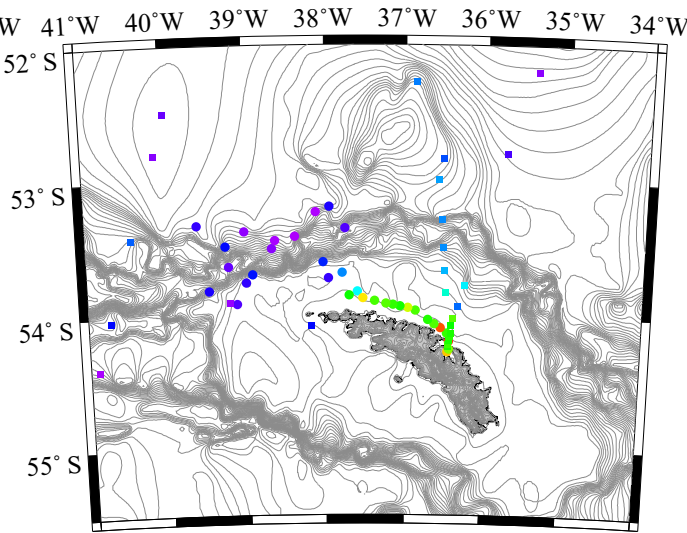

(b)
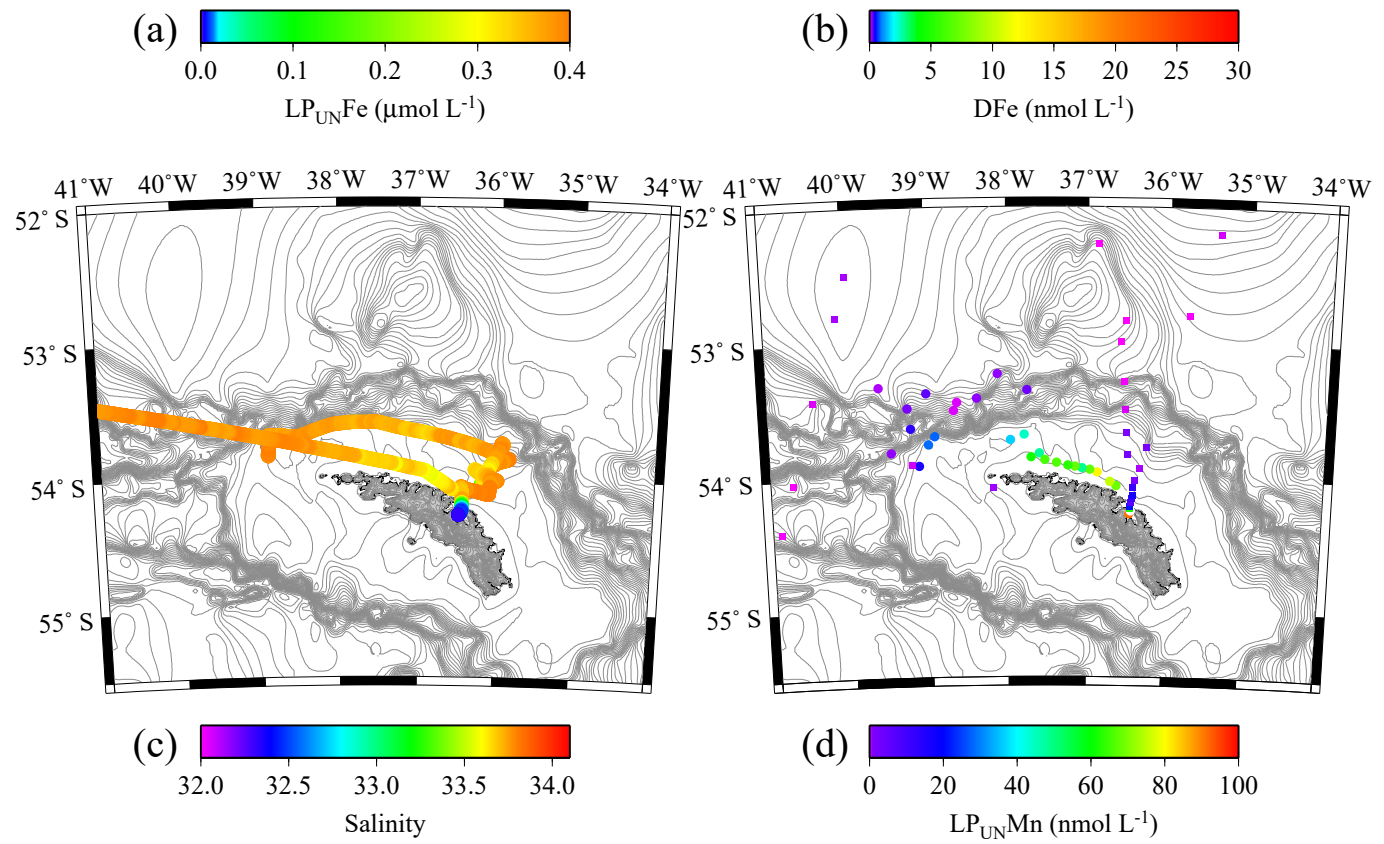

Figure 6. Tow fish seawater samples: concentrations of leachable particulate $\mathrm{Fe}\left(\mathrm{LP} \mathrm{Un}_{\mathrm{Fe}}\right)$ of unfiltered seawater samples (a), dissolved Fe (DFe) (b), salinity (c), and leachable particulate $\mathrm{Mn}\left(\mathrm{LP}_{\mathrm{Un}} \mathrm{Mn}\right)$ in unfiltered seawater samples (d) in surface waters collected during JR247 (circles) and JR274 (squares) around South Georgia. The highest LP $\mathrm{Un}_{\mathrm{Fe}}$ concentration was recorded in a single sample in Cumberland Bay, reaching $2.2 \mu \mathrm{mol} \mathrm{L}^{-1}$. Because of generally lower concentrations, we excluded this data point in panel (a). Isobath are represented by grey lines (GEBCO gridded bathymetry data).

$\left(\mathrm{LP}_{\mathrm{Un}} \mathrm{Fe}=82.26 \mathrm{nmol} \mathrm{L}^{-1}\right.$; water depth $\left.=255 \mathrm{~m}\right)$ to site $\# 13$ at $100 \mathrm{~m}$ depth $\left(\mathrm{LP}_{\mathrm{Un}} \mathrm{Fe}=34.06 \mathrm{nmol} \mathrm{L}^{-1}\right.$; water depth $=130 \mathrm{~m})$ to site $\# 11 / 12$ between 200 and $400 \mathrm{~m}$ depth $\left(\mathrm{LP}_{\mathrm{Un}} \mathrm{Fe} \sim 10.18 \mathrm{nmol} \mathrm{L}^{-1}\right.$; water depth $\left.=750 \mathrm{~m}\right)$ (Fig. 4 and Table 1). A similar decrease was observed for the SAPS Fe data: from site $\# 14$ at $150 \mathrm{~m}$ depth $\left(\mathrm{PFe}=31.12 \mathrm{nmol} \mathrm{L}^{-1}\right)$ to site $\# 13$ at $100 \mathrm{~m}$ depth $(\mathrm{PFe}=$ $10.23 \mathrm{nmol} \mathrm{L}^{-1}$ ). The decrease of $\mathrm{PFe}$ and $\mathrm{LP}_{\mathrm{Un}} \mathrm{Fe}$ with increasing distance to the coast is in agreement with previous observations for the western subarctic Pacific (Lam and Bishop, 2008), which reported elevated LFe concentrations in the range of 0.6 to $3.8 \mathrm{nmol} \mathrm{L}^{-1}$ in subsurface waters between 100 and $200 \mathrm{~m}$ depth along the Kamchatka shelf and related this observation to offshore water mass transport. However, we assume that particles in the deep particulate $\mathrm{Fe}$ maximum are not transported over very large distances, due to their tendency to sink, and thus do not significantly contribute to the offshore Fe supply (Sect. 3.4).

Consistent with the observed $P$ and $\mathrm{LP}_{\mathrm{Un}}$ distributions, elevated dissolved metal concentrations at depths between 200 and $400 \mathrm{~m}$ at site $\# 11 / 12$ indicated that trace-metal-enriched shelf bottom waters were transported offshore (Fig. 7). However, dissolved trace metal concentrations were more variable than $P$ and $\mathrm{LP}_{\mathrm{Un}}$, and in the case of DMn they were highest at depths at shelf edge site \#11/12. Notwithstanding the above issue, for horizontal flux calculations we used the entire DFe 


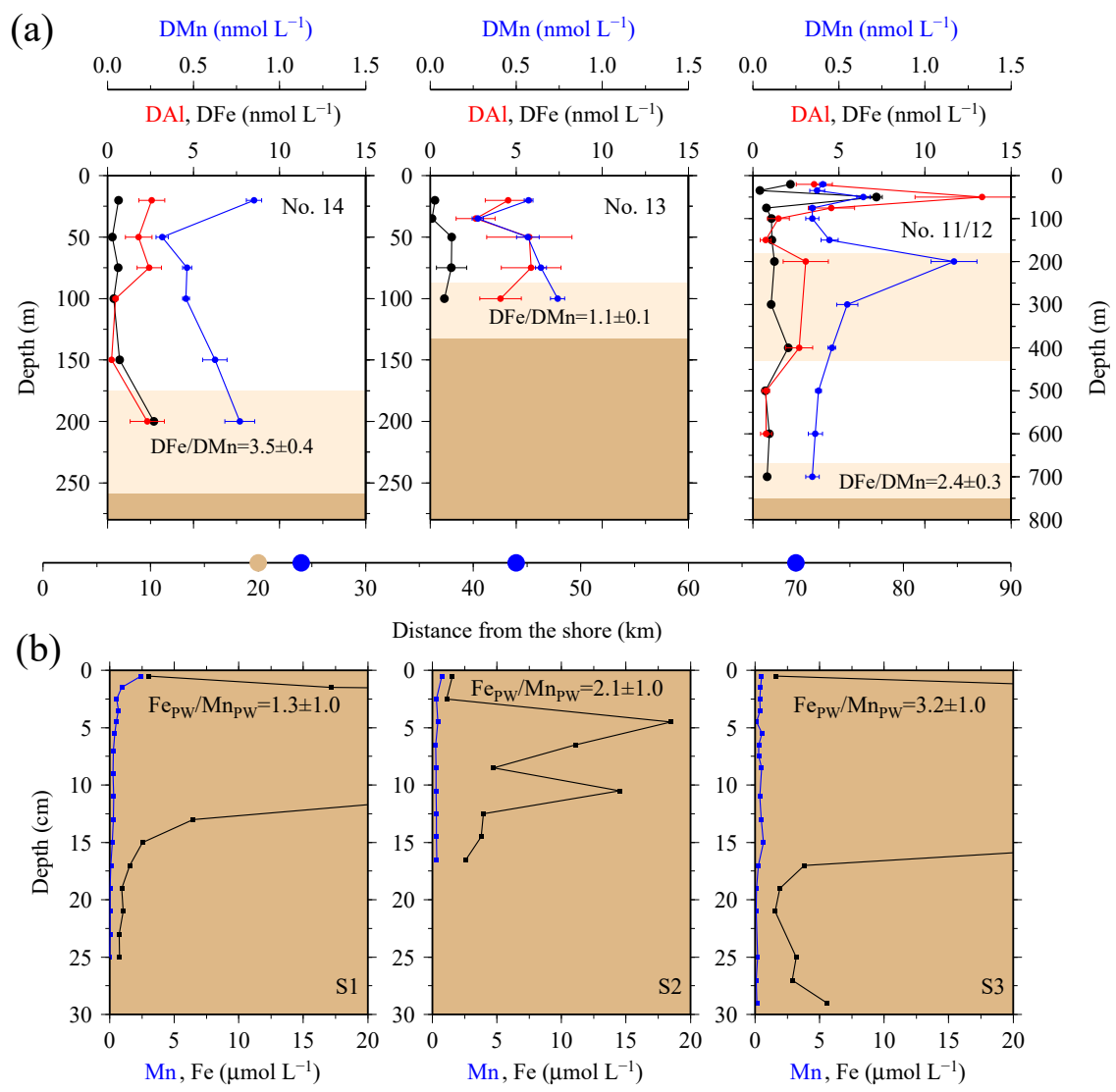

Figure 7. (a) OTE seawater samples: from left to right, concentrations of dissolved iron (DFe), aluminium (DAl), and manganese (DMn) for the two shelf sites (\#14,\#13) and the shelf edge site (\#11/12). Note different depth scaling. Error bars represent the standard deviation of the analysis. Pink areas represent the zone of resuspended sediments in the water column. The DFe / DMn ratios of the seawaters collected within the pink zone are indicated. (b) sediment core samples: diagram of S1, S2, and S3 displaying the Fe (black) and Mn (blue) content in pore waters of the three sediment cores. Values off-axis can be found in Table 4. Shown are average Fe $\mathrm{PW}_{\mathrm{PW}} \mathrm{Mn}_{\mathrm{PW}} \mathrm{ratios}\left(\mathrm{mol} \mathrm{mol}{ }^{-1}\right.$ ) of top surface layer $(1 \mathrm{~cm})$ for sites S1, S2, and S3. Dots on the distance scaling in the middle represent the distance of each water column station (blue) and sediment core (brown) station to the nearest shore.

data set for water depths between 100 and $400 \mathrm{~m}$. Average $\mathrm{DFe}$ concentrations in this depth range were highly variable and did not follow an exponential or power law function with distance from the coast (Fig. S5), which is necessary to determine scale length and horizontal diffusivity $\left(K_{\mathrm{h}}\right)$ (de Jong et al., 2012). As a result, horizontal flux calculations from the data could not be executed.

The distribution of dissolved trace metals in surface waters indicated that there was a limited transfer of DFe beyond the shelf break into the bloom region. Surface samples showed that DFe concentrations were strongly enriched in surface waters on the shelf $\left(0.3-25.9 \mathrm{nmol} \mathrm{L}^{-1}\right.$, Fig. $\left.6 \mathrm{~b}\right)$, while DFe concentrations beyond the shelf break decreased abruptly to concentrations $<0.2 \mathrm{nmol} \mathrm{L}^{-1}$ (Fig. 6b). This indicates that DFe was quickly removed from ACC surface waters following passage of the island. However, previous studies in the region suggest DFe transfer beyond the shelf break of South Georgia (Borrione et al., 2014; Nielsdóttir et al., 2012). Nielsdóttir et al. (2012) reported surface waters downstream of the island shelf with up to $2 \mathrm{nmolDFe} \mathrm{L}^{-1}$, with seasonal variations and highest concentrations during austral summer in January/February 2008. Dissolved Fe data from JR247 (2011) and JR274 (2012) were also obtained during the summer season but indicated rapid reduction in concentrations through mixing with DFe-depleted ACC water, biological uptake, and/or particle scavenging (authigenic precipitation).

\subsection{Iron budget in the bloom region}

Large seasonal phytoplankton blooms downstream of South Georgia recorded by Earth-observing satellites are initiated by Fe supplied by the South Georgia island-shelf system during the passage of ACC waters (Fig. 1) (Borrione et al., 2014; Nielsdóttir et al., 2012). Based on our study, the main DFe sources during this passage of the ACC were benthic release and vertical mixing, release of DFe from krill and krill faecal pellets, and supply of particles from run-off and glacial melt- 
water. In the following sections we will discuss the strength of each DFe source in the bloom region ca. $1250 \mathrm{~km}$ downstream of the island and estimate how much DFe is required to stimulate the elevated primary productivity in that region. Because of the lack of observational data for the region, this part of the study combines literature values from different Southern Ocean studies. This approach contains large uncertainties, which are discussed in detail in Sect. 3.4.6.

\subsubsection{Phytoplankton Fe requirements in the phytoplankton bloom region}

The surface ocean in the vicinity of South Georgia during the austral summer features strongly elevated biomass production (Gilpin et al., 2002) and represents the largest known $\mathrm{CO}_{2}$ sink in the ACC $\left(12.9 \mathrm{mmol} \mathrm{C} \mathrm{m}^{-2} \mathrm{~d}^{-1}\right.$; Jones et al., 2012). The Fe requirements of the phytoplankton community in austral summer within the bloom that reaches several hundred kilometres downstream of the island were determined by combining satellite-depth-integrated net primary production data derived from a phytoplankton pigment adsorption $\left(\alpha_{\mathrm{ph}}\right)$-based model $\left(62 \pm 21 \mathrm{mmol} \mathrm{C} \mathrm{m}^{-2} \mathrm{~d}^{-1} ; \mathrm{Ma}\right.$ et al., 2014) over the period of 2003-2010 with an average intracellular $\mathrm{Fe} / \mathrm{C}$ ratio obtained from five Southern Ocean diatom species $\left(5.23 \pm 2.84 \mu \mathrm{mol} \mathrm{Fe} \mathrm{mol}{ }^{-1} \mathrm{C}\right.$; Strzepek et al., 2011). This approach yielded an approximate Fe requirement of $0.33 \pm 0.11 \mu \mathrm{mol} \mathrm{DFe} \mathrm{m}{ }^{-2} \mathrm{~d}^{-1}$ for the phytoplankton community (Fig. 8). For a more detailed description of the applied values and calculations see Sect. S4.

\subsubsection{Horizontal and vertical mixing}

De Jong et al. (2012) reported that horizontal and vertical advective, diffusive (diapycnal), and deep winter mixing downstream (1250-1570 km) of the Antarctic Peninsula (between 51 and $59^{\circ} \mathrm{S}$ ) supplied DFe to the surface waters in quantities that exceeded the DFe requirement of primary producers during austral summer $\left(0.13 \pm 0.04 \mu \mathrm{mol} \mathrm{DFe} \mathrm{m}^{-2} \mathrm{~d}^{-1}\right)$. In their study region, de Jong et al. (2012) determined that $\sim 0.30 \pm 0.22 \mu \mathrm{mol} \mathrm{DFe} \mathrm{m}^{-2} \mathrm{~d}^{-1}$ was supplied by horizontal and vertical fluxes, of which $91 \%$ of the vertical flux was attributed to Ekman upwelling (advective term), and $43 \%$ of the entire DFe flux was supplied by deep winter mixing. Tagliabue et al. (2014) reported similar model estimates for the region that is located south of the PF and characterized by strong Ekman upwelling and winter entrainment.

For the bloom region downstream of South Georgia, model calculations by Tagliabue et al. (2014) indicated that less than $0.0003 \mu \mathrm{mol} \mathrm{DFe} \mathrm{m}^{-2} \mathrm{~d}^{-1}$ was supplied by diapycnal mixing and that $\sim-0.0027 \mu \mathrm{molDFe} \mathrm{m}^{-2} \mathrm{~d}^{-1}$ was removed by Ekman downwelling. For the vertical flux component, this yields an overall loss of DFe of $\sim-0.002 \mu \mathrm{mol} \mathrm{DFe} \mathrm{m}^{-2} \mathrm{~d}^{-1}(0.0003+(-0.0027))$ in the bloom region north of South Georgia (Fig. 8).

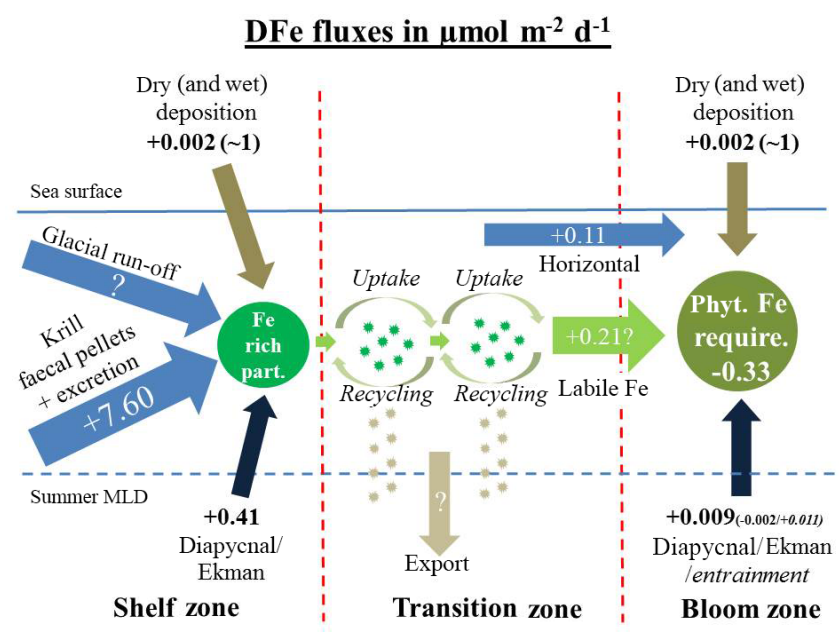

Figure 8. Sketch of DFe fluxes on the shelf, in the transition zone, and in the downstream blooming region, separated by the red dashed lines. (left sketch) The dissolved Fe fluxes on the shelf that together generate Fe rich biogenic and lithogenic particles (dark green). These are transferred offshore (light green arrows) following the ACC to open-ocean sites (sketch in the middle). Iron-enriched particles (dark green) in the transition zone are recycled and supplement DFe requirements of the phytoplankton community in the transition zone. During each cycle of recycling and uptake an unknown Fe fraction is lost by vertical export. (right sketch) The dissolved Fe fluxes in the blooming zone.

Because the sampling in our study was not suitable for calculations of the horizontal flux, we applied the horizontal flux estimates from de Jong et al. (2012) for our own $\mathrm{Fe}$ budget. For a region ca. $1250 \mathrm{~km}$ downstream of a source, calculations according to de Jong et al. (2012) suggest that ca. $0.11 \pm 0.03 \mu \mathrm{mol} \mathrm{DFe} \mathrm{m}{ }^{-2} \mathrm{~d}^{-1}$ is supplied to the bloom region by horizontal advection and diffusion (Fig. 8).

\subsubsection{Deep winter mixing}

The entrainment of new DFe during winter represents an important $\mathrm{Fe}$ source to surface waters in the Southern Ocean (de Jong et al., 2012; Tagliabue et al., 2014). Elevated DFe concentrations in subsurface waters support primary production in the austral spring following entrainment by deep winter mixing. Model estimates showed that DFe supplied by winter mixing, together with diapycnal mixing, matches the $\mathrm{Fe}$ requirements at most low-productivity sites in the Southern Ocean. However, deep winter mixing at the highly productive sites north of South Georgia supplies only $0.011 \mu \mathrm{mol} \mathrm{m}^{-2} \mathrm{~d}^{-1}$ (Tagliabue et al., 2014) (Fig. 8). Later in the season primary productivity in surface waters is considered to rely strongly on Fe derived from recycling of biogenic material (Boyd et al., 2015). 


\subsubsection{Dust deposition}

Dissolved Fe supplied by the deposition of aeolian dust is considered to be an important source to the Southern Ocean (Conway et al., 2015; Gabric et al., 2010; Gassó and Stein, 2007). Aeolian flux model estimates, supplied by Borrione et al. (2014) using a regional South Georgia model, suggested that up to $8 \mu \mathrm{mol} \mathrm{Fe} \mathrm{m}{ }^{-2} \mathrm{~d}^{-1}$ is delivered to the bloom regions downstream of South Georgia by dry and wet deposition. However, reliable dry- and wet-deposition estimates for the Southern Ocean are limited. Data from the South Atlantic along $40^{\circ} \mathrm{S}, \sim 1000 \mathrm{~km}$ north of South Georgia, showed that rather low levels of DFe $\left(\sim 0.002 \mu \mathrm{mol} \mathrm{m}^{-2} \mathrm{~d}^{-1}\right)$ are supplied by dry deposition (Chance et al., 2015). In addition, $\sim 1.0 \pm 1.2 \mu \mathrm{mol} \mathrm{DFe} \mathrm{m}^{-2} \mathrm{~d}^{-1}$ are delivered sporadically to the $40^{\circ} \mathrm{S}$ area by wet deposition (Chance et al., 2015). However, even when assuming that similar wet-deposition fluxes occur north of South Georgia, fertilization with DFe is temporally and spatially limited. Furthermore, it is very unlikely that such sporadic events could cause long-lasting and far-extending phytoplankton blooms strictly constrained between the PF and the SACCF.

\subsubsection{Luxury Fe uptake on the shelf}

Our conservative estimate of DFe supply to the bloom region by vertical/horizontal mixing, deep winter entrainment, and dust deposition $\left(<0.12 \mu \mathrm{mol} \mathrm{Fe} \mathrm{m}^{-2} \mathrm{~d}^{-1}\right)$ covers only $\sim 30 \%$ of the estimated phytoplankton require-

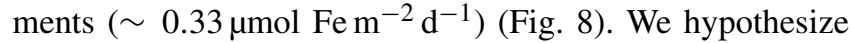
that the missing supply of $\sim 0.21 \mu \mathrm{mol} \mathrm{DFe} \mathrm{m}^{-2} \mathrm{~d}^{-1}$ is supplied to the bloom region through the offshore advection of phytoplankton cells that are enriched in labile Fe. It has been demonstrated that Fe-rich biogenic particles can be created by luxury iron uptake of diatoms (Iwade et al., 2006; Marchetti et al., 2009). Using bottle incubation experiments, Iwade et al. (2006) showed that under Fe-replete conditions the coastal diatom Chaetoceros sociale stores more intracellular Fe than needed for the production of essential enzymes and proteins. We therefore hypothesize that phytoplankton cells that grew under excess nutrient supply on the South Georgia shelf stored more Fe than needed for their metabolic processes. Due to subsequent cycles of grazing, lysis or bacterial decomposition, this iron can be remobilized in surface waters and made available for renewed phytoplankton uptake.

High $\mathrm{Fe}$ recycling efficiencies, described by the $f e$ ratio (Boyd et al., 2005), are required to maintain the cycle of remineralization and uptake in the euphotic zone. This counteracts the loss of particulate Fe by vertical export. Boyd et al. (2015) reported the highest recycling efficiencies of $\sim 90 \%$ for subantarctic DFe-depleted waters such as downstream of South Georgia. Further, these workers showed that the degree of recycling is controlled by the abundance of prokaryotes with a high Fe quota, such as cyanobacteria, and particularly by grazing zooplankton. The waters off South Georgia feature among the highest biomasses worldwide of metazoan grazers (Atkinson et al., 2001). These large grazers, chiefly copepods and Antarctic krill, are able to efficiently ingest large diatoms, including species that are known to store luxury iron (Atkinson, 1994; Hamm et al., 2003), thereby disintegrating cell membranes and releasing trace metals.

In recent years it has become apparent that the recycling of biogenic particles in the euphotic zone is a critical mechanism that maintains primary production, especially when the dissolved nutrient pools become exhausted (Boyd et al., 2015; Tagliabue et al., 2014). However, uncertainties remain over the degree to which $\mathrm{Fe}$ is lost during each cycle of uptake and remineralization. Thus more research is needed, especially fieldwork that encompasses the community structures (bacteria, phytoplankton, zooplankton, and higher predators; Ratnarajah et al., 2017; Wing et al., 2014), the degree of recycling for macro- and micro-nutrients in the euphotic zone, and loss of Fe through vertical export.

An alternative explanation to our suggestion that recycling of luxury-iron-enriched biota contributes to the downstream bloom is that iron is adsorbed directly onto particles that are advected directly offshore. For example freshly precipitated $\mathrm{Fe}(\mathrm{III})$ oxyhydroxides $\left(\mathrm{FeOOH} \times \mathrm{nH}_{2} \mathrm{O}\right)$ may be adsorbed onto biogenic and non-biogenic material. Iron freshly absorbed onto biogenic and non-biogenic material can be released and incorporated by phytoplankton and bacteria. However, the bioavailability of adsorbed and inorganic $\mathrm{Fe}$ changes over time. Both Wells et al. (1991) and Chen and Wang (2001) demonstrated that the bioavailability of freshly precipitated $\mathrm{FeOOH}$ and $\mathrm{Fe}$ adsorbed onto colloids/inorganic particles decreases over time. This is primarily due to the dehydration of the loosely packed structure that is subsequently transferred into amorphous $\mathrm{FeOOH}$ in the mineral structure goethite. Because of this we suggest that the majority of $\mathrm{Fe}$ from inorganic $\mathrm{FeOOH}$ or $\mathrm{Fe}$ adsorbed onto particles must be released and utilized in an early stage of the voyage, mainly on the shelf or shortly after the shelf break.

\subsubsection{Budget uncertainties}

Estimates for $\mathrm{Fe}$ budgets are challenging and often contain large uncertainties. This is primarily due to the lack of siteand time-specific flux data. Moreover, the mean annual estimates necessary for reliable supply calculations reach a high level of accuracy only after the same region has been monitored multiple times to cover seasonal and annual anomalies. In the following, we will discuss the uncertainty of the different Fe fluxes in the blooming region north of South Georgia.

We identified three main processes that together account for $\sim 98 \%$ of the total Fe flux in the blooming region and thus contribute largest uncertainties: the horizontal flux, dry/wet deposition, and winter entrainment. Horizontal flux estimates of this study rely on literature values that were 
collected offshore of the Antarctic Peninsula. In contrast, South Georgia is an island with a confined shelf region, and thus horizontal DFe fluxes may differ greatly. Furthermore, we showed not only that dry-deposition dust fluxes are generally low but also that the Fe flux can be supplemented strongly by sporadic wet-deposition events $(\sim 1.0 \pm$ $1.2 \mu \mathrm{mol} \mathrm{DFe} \mathrm{m}^{-2} \mathrm{~d}^{-1}$ ) (Chance et al., 2015). Atmospheric fluxes are variable, illustrated by the large standard deviation of the wet-deposition $\mathrm{Fe}$ fluxes obtained at $40^{\circ} \mathrm{S}$. Furthermore, to determine the magnitude of the seasonal DFe winter entrainment reliable estimates of the winter mixing layer depth (WMLD) and the ferrocline are required. Even though the WMLD can be estimated very precisely using Argo float data, the depth of ferrocline in Tagliabue et al. (2014) is based on 140 unique observations distributed over the entire Southern Ocean. Due to this, regional anomalies are not captured. In addition to the DFe fluxes in the blooming region, we also assume that the biological Fe demand estimated for the phytoplankton community contributes a large error. The biological $\mathrm{Fe}$ requirements were determined using satellitederived net primary production data and an average intracellular $\mathrm{Fe} / \mathrm{C}$ ratio derived from five different diatom species native to the Southern Ocean. Both parameters are not well constrained, and because of the lack of observational data we applied the lowest intracellular $\mathrm{Fe} / \mathrm{C}$ ratio available in the literature (Strzepek et al., 2011). However, we found that even small changes of both parameters change the estimated $\mathrm{Fe}$ availability in the bloom region strongly. Nevertheless, flux estimates even with large uncertainties can help us understand the degree of the nutrient supply vs. consumption by organisms and help to pinpoint the limitation of the estimates made. To ultimately reduce the level of uncertainty and to improve our biogeochemical models, more observational data from the bloom region north of South Georgia are required.

\section{Conclusions}

Shelf-sediment-derived $\mathrm{Fe}$ and Fe released from Antarctic krill significantly contribute to the DFe distribution in the shelf waters around South Georgia. Nevertheless, DFe enriched in shelf waters are not effectively advected to the phytoplankton bloom region downstream of the island. Together with other Fe supplies - such as aeolian dust, deep winter mixing, and diapycnal mixing - the horizontal advection contributes only $\sim 30 \%$ to the Fe requirements of a phytoplankton bloom downstream of South Georgia. We therefore hypothesize that the majority of the $\mathrm{Fe}$ is derived from remineralization of $\mathrm{Fe}$-enriched phytoplankton cells and biogenic particles that are transported with the water masses into the bloom region.

While we highlight the importance of grazers and the cycling of various particulate Fe phases in the Fe fertilization of the South Georgia bloom, more work is needed to clarify the transport mechanisms of dissolved and particulate Fe.

Data availability. The entire data set discussed in the paper is provided in the manuscript (Tables 1, 2, 4, and 5) and Supplement (Table S1 and S2).

Supplement. The supplement related to this article is available online at: https://doi.org/10.5194/bg-15-4973-2018-supplement.

Author contributions. CS, KS, EPA, SF, and AAt designed the experiments for JC247. CS, MDP, and AAt performed the sampling and krill incubation experiments during JC247. CS and MC analysed the trace metal samples at NOCS. EPA sampled the seawater during JC274. Samples from JC274 were analysed by CS and MC. AAq, WBH, and RAM designed the experiments for JR55, and AAq analysed the samples. CS prepared the manuscript with contributions from all co-authors.

Competing interests. The authors declare that they have no conflict of interest.

Acknowledgements. We would like to thank the officers and crew of RRS James Clark Ross for assistance with the pelagic sampling and those of RRS James Cook for the benthic coring. In addition, we thank the two anonymous reviewers for reviewing the manuscript. This work forms part of the NERC-AFI grant AFI9/07 to Angus Atkinson and Eric P. Achterberg (NE/F01547X/1). Rachel A. Mills was funded by NERC grants NE/01249X/1 and NE/H004394/1. William B. Homoky was supported by NERC fellowship NE/K009532/1.

Edited by: Laurent Bopp

Reviewed by: two anonymous referees

\section{References}

Achterberg, E. P., Steigenberger, S., Marsay, C. M., LeMoigne, F. A. C., Painter, S. C., Baker, A. R., Connelly, D. P., Moore, C. M., Tagliabue, A., and Tanhua, T.: Iron Biogeochemistry in the High Latitude North Atlantic Ocean, Sci. Rep., 8, 1-12, 2018.

Atkinson, A.: Diets and feeding selectivity among the epipelagic copepod community near South Georgia in summer, Polar Biol., 14, 551-560, 1994.

Atkinson, A., Whitehouse, M. J., Priddle, J., Cripps, G. C., Ward, P., and Brandon, M. A.: South Georgia, Antarctica: a productive, cold water, pelagic ecosystem, Mar. Ecol.-Prog. Ser., 216, 279308, 2001.

Berger, C. J. M., Lippiatt, S. M., Lawrence, M. G., and Bruland, K. W.: Application of a chemical leach technique for estimating labile particulate aluminum, iron, and manganese in the Columbia 
River plume and coastal waters off Oregon and Washington, J. Geophys. Res., 113, 1-16, 2008.

Bonneville, S., Behrends, T., and Van Cappellen, P.: Solubility and dissimilatory reduction kinetics of iron(III) oxyhydroxides: A linear free energy relationship, Geochim. Cosmochim. Ac., 73, 5273-5282, 2009.

Borrione, I., Aumont, O., Nielsdóttir, M. C., and Schlitzer, R.: Sedimentary and atmospheric sources of iron around South Georgia, Southern Ocean: a modelling perspective, Biogeosciences, 11, 1981-2001, https://doi.org/10.5194/bg-11-1981-2014, 2014.

Boudreau, B. P. and Scott, M. R.: A model for the diffusioncontrolled growth of deep-sea manganese nodules, Am. J. Sci., 278, 903-929, 1978.

Boyd, P. W., Law, C. S., Hutchins, D. A., Abraham, E. R., Croot, P. L., Ellwood, M., Frew, R. D., Hadfield, M., Hall, J., Handy, S., Hare, C., Higgins, J., Hill, P., Hunter, K. A., LeBlanc, K., Maldonado, M. T., McKay, R. M., Mioni, C., Oliver, M., Pickmere, S., Pinkerton, M., Safi, K., Sander, S., Sanudo-Wilhelmy, S. A., Smith, M., Strzepek, R., Tovar-Sanchez, A., and Wilhelm, S. W.: FeCycle: Attempting an iron biogeochemical budget from a mesoscale SF6 tracer experiment in unperturbed low iron waters, Global Biogeochem. Cy., 19, 1-13, 2005.

Boyd, P. W., Strzepek, R. F., Ellwood, M. J., Hutchins, D. A., Nodder, S. D., Twining, B. S., and Wilhelm, S. W.: Why are biotic iron pools uniform across high- and low-iron pelagic ecosystems?, Global Biogeochem. Cy., 29, 1028-1043, 2015.

Browning, T. J., Bouman, H. A., Henderson, G. M., Mather, T. A., Pyle, D. M., Schlosser, C., Woodward, E. M. S., and Moore, C. M.: Strong responses of Southern Ocean phytoplankton communities to volcanic ash, Geophys. Res. Lett., 41, 1-7, 2014.

Buesseler, K. O., Andrews, J. E., Pike, S. M., and Charette, M. A.: The Effects of Iron Fertilization on Carbon Sequestration in the Southern Ocean, Science, 304, 414-417, 2004.

Canfield, D. E. and Thamdrup, B.: Towards a consistent classification scheme for geochemical environments, or, why we wish the term "suboxic" would go away, Geobiology, 7, 385-392, 2009.

Cassar, N., Bender, M. L., Barnett, B. A., Fan, S., Moxim, W. J., Levy II, H., and Tilbrook, B.: The Southern Ocean Biological Response to Aelian Iron Input, Science, 317, 1067-1070, 2007.

Chance, R., Jickells, T. D., and Baker, A. R.: Atmospheric trace metal concentrations, solubility and deposition fluxes in remote marine air over the south-east Atlantic, Mar. Chem., 177, 45-55, 2015

Charette, M. A., Gonneea, M. E., Morris, P., Statham, P., Fones, G., Planquette, H., Salter, I., and Garabato, A. N.: Radium isotopes as tracers of iron sources fueling a Southern Ocean phytoplankton bloom, Deep-Sea Res. Pt. II, 54, 1989-1998, 2007.

Chase, Z., Hales, B., Cowles, T., Schwartz, R., and van Geen, A.: Distribution and variability of iron input to Oregon coastal waters during the upwelling season, J. Geophys. Res., 110, 1-14, 2005.

Chen, M. and Wang, W.-X.: Bioavailability of natural colloid-bound iron to marine plankton: Influences of colloidal size and aging, Limnol. Oceanogr., 46, 1956-1967, 2001.

Conway, T. M., Wolff, E. W., Rothlisberger, R., Mulvaney, R., and Elderfield, H. E.: Constraints on soluble aerosol iron flux to the Southern Ocean at the Last Glacial Maximum, Nat. Commun., 6, $1-9,2015$.

de Boyer Montégut, C., Madec, G., Fischer, A. S., Lazar, A., and Iudicone, D.: Mixed layer depth over the global ocean: An ex- amination of profile data and a profile-based climatology, J. Geophys. Res., 109, 1-20, 2004.

de Jong, J., Schoemann, V., Lannuzel, D., Croot, P., de Baar, H. J. W., and Tison, J. L.: Natural iron fertilization of the Atlantic sector of the Southern Ocean by continental shelf sources of the Antarctic Peninsula, J. Geophys. Res., 117, 1-25, 2012.

Fielding, S., Watkins, J. L., Trathan, P. N., Enderlein, P., Waluda, C. M., Stowasser, G., Tarling, G. A., and Murphy, E. J.: Interannual variability in Antarctic krill (Euphausia superba) density at South Georgia, Southern Ocean: 1997-2013, ICES J. Mar. Sci., 71, 2578-2588, 2014.

Fitzsimmons, J. N. and Boyle, E. A.: Both soluble and colloidal iron phases control dissolved iron variability in the tropical North Atlantic Ocean, Geochim. Cosmochim. Ac., 125, 539-550, 2014.

Gabric, A. J., Cropp, R. A., McTainsh, G. H., Johnston, B. M., Butler, H., Tilbrook, B., and Keywood, M.: Australian dust storms in 2002 and 2003 and their impact on Southern Ocean biogeochemistry, Global Biogeochem. Cy., 24, 1-17, 2010.

Gao, Y., Kaufman, Y. J., Tanré, D., Kolber, D., and Falkowski, P. G.: Seasonal distributions of aeolian iron fluxes to the global ocean, Geophys. Res. Lett., 28, 29-32, 2001.

Gassó, S. and Stein, A. F.: Does dust from Patagonia reach the subAntarctic Atlantic Ocean?, Geophys. Res. Lett., 34, 1-5, 2007.

German, C. R., Casciotti, K. A., Dutay, J.-C., Heimbürger, L. E., Jenkins, W. J., Measures, C. I., Mills, R. A., Obata, H., Schlitzer, R., Tagliabue, A., Turner, D. R., and Whitby, H.: Hydrothermal impacts on trace element and isotope ocean biogeochemistry, Philos. T. R. Soc. A, 374, 1-19, 2016.

Gerringa, L. J. A., Alderkamp, A.-C., Laan, P., Thuróczy, C.-E., De Baar, H. J. W., Mills, M. M., van Dijken, G. L., van Haren, H., and Arrigo, K. R.: Iron from melting glaciers fuels the phytoplankton blooms in Amundsen Sea (Southern Ocean): Iron biogeochemistry, Deep-Sea Res. Pt. II, 71-76, 16-31, 2012.

Giering, S. L. C., Steigenberger, S., Achterberg, E. P., Sanders, R., and Mayor, D. J.: Elevated iron to nitrogen recycling by mesozooplankton in the Northeast Atlantic Ocean, Geophys. Res. Lett., 39, L12608, https://doi.org/10.1029/2012g1051776, 2012.

Gilpin, L. C., Priddle, J., Whitehouse, M. J., Savidge, G., and Atkinson, A.: Primary production and carbon uptake dynamics in the vicinity of South Georgia-balancing carbon fixation and removal, Mar. Ecol.-Prog. Ser., 242, 51-62, 2002.

Hamm, C. E., Merkel, R., Springer, O., Jurkojc, P., Maier, C., Prechtel, K., and Smetacek, V.: Architecture and material properties of diatom shells provide effective mechanical protection, Nature, 421, 841-843, 2003.

Ho, T.-Y., Quigg, A., Finkel, Z. V., Milligan, A. J., Wyman, K., Falkowski, P. G., and Morel, F. M. M.: The elemental composition of some marine phytoplankton, J. Phycol., 39, 1145-1159, 2003.

Homoky, W. B., Hembury, D. J., Hepburn, L. E., Mills, R. A., Statham, P. J., Fones, G. R., and Palmer, M. R.: Iron and manganese diagenesis in deep sea volcanogenic sediments and the origins of pore water colloids, Geochim. Cosmochim. Ac., 75, 5032-5048, 2011.

Homoky, W. B., Severmann, S., McManus, J., Berelson, W. M., Riedel, T. E., Statham, P. J., and Mills, R. A.: Dissolved oxygen and suspended particles regulate the benthic flux of iron from continental margins, Mar. Chem., 134-135, 59-70, 2012. 
Homoky, W. B., Weber, T., Berelson, W. M., Conway, T. M., Henderson, G. M., van Hulten, M., Jeandel, C., Severmann, S., and Tagliabue, A.: Quantifying trace element and isotope fluxes at the ocean-sediment boundary: a review, Philos. T. R. Soc. A, 374, https://doi.org/10.1098/rsta.2016.0246, 2016.

Hutchins, D. A. and Bruland, K. W.: Grazer-mediated regeneration and assimilation of $\mathrm{Fe}, \mathrm{Zn}$ and $\mathrm{Mn}$ from planktonic prey, Mar. Ecol.-Prog. Ser., 110, 259-269, 1994.

Iwade, S., Kuma, K., Isoda, Y., Yoshida, M., Kudo, I., Nishioka, J., and Suzuki, K.: Effect of high iron concentrations on iron uptake and growth of a coastal diatom Chaetoceros sociale, Aquat. Microb. Ecol., 43, 177-191, 2006.

Jones, E. M., Bakker, D. C. E., Venables, H. J., and Watson, A. J.: Dynamic seasonal cycling of inorganic carbon downstream of South Georgia, Southern Ocean, Deep-Sea Res. Pt. II, 59-60, 25-35, 2012.

Jones, E. M., Bakker, D. C. E., Venables, H. J., and HardmanMountford, N. J.: Seasonal cycle of CO2 from the sea ice edge to island blooms in the Scotia Sea, Southern Ocean, Mar. Chem., 177, 490-500, 2015.

Kalnejais, L. H., Martin, W. R., and Bothner, M. H.: The release of dissolved nutrients and metals from coastal sediments due to resuspension, Mar. Chem., 121, 224-235, 2010.

Klar, J. K., Homoky, W. B., Statham, P. J., Birchill, A. J., Harris, E. L., Woodward, E. M. S., Silburn, B., Cooper, M. J., James, R. H., Connelly, D. P., Chever, F., Lichtschlag, A., and Graves, C.: Stability of dissolved and soluble Fe(II) in shelf sediment pore waters and release to an oxic water column, Biogeochemistry, 135, 49-67, 2017.

Korb, R. E., Whitehouse, M. J., and Ward, P.: SeaWiFS in the southern ocean: spatial and temporal variability in phytoplankton biomass around South Georgia, Deep-Sea Res. Pt. II, 51, 99-116, 2004.

Koschinsky, A., Winkler, A., and Fritsche, U.: Importance of different types of marine particles for the scavenging of heavy metals in the deep-sea bottom water, Appl. Geochem., 18, 693-710, 2003

Kurapov, A. L., Allen, J. S., and Egbert, G. D.: Combined Effects of Wind-Driven Upwelling and Internal Tide on the Continental Shelf, J. Phys. Oceanogr., 40, 737-756, 2010.

Lam, P. J. and Bishop, J. K. B.: The continental margin is a key source of iron to the HNLC North Pacific Ocean, Geophys. Res. Lett., 35, 1-5, 2008.

Liu, X. and Millero, F. J.: The solubility of iron in seawater, Mar. Chem., 77, 43-54, 2002.

Ma, S., Tao, Z., Yang, X., Yu, Y., Zhou, X., M, W., and Li, Z.: Estimation of marine primary productivity from satellite-derived phytoplankton absorption data, IEEE J.-Stars, 7, 3084-3092, 2014.

Marchetti, A., Parker, M. S., Moccia, L. P., Lin, E. O., Arrieta, A. L., Ribalet, F., Murphy, M. E. P., Maldonado, M. T., and Armbrust, E. V.: Ferritin is used for iron storage in bloom-forming marine pennate diatoms, Nature, 457, 467-470, 2009.

Marsay, C. M., Sedwick, P. N., Dinniman, M. S., Barrett, P. M., Mack, S. L., and McGillicuddy, D. J.: Estimating the benthic efflux of dissolved iron on the Ross Sea continental shelf, Geophys. Res. Lett., 41, 7576-7583, 2014.

Meredith, M. P., Brandon, M. A., Murphy, E. J., Trathan, P. N., Thorpe, S. E., Bone, D. G., Chernyshkov, P. P., and Sushin, V.
A.: Variability in hydrographic conditions to the east and northwest of South Georgia, 1996-2001, J. Mar. Syst., 53, 143-167, 2005.

Milne, A., Schlosser, C., Wake, B. D., Achterberg, E. P., Chance, R., Baker, A. R., Forryan, A., and Lohan, M. C.: Particulate phases are key in controlling dissolved iron concentrations in the (sub)tropical North Atlantic, Geophys. Res. Lett., 44, $2377-$ 2387, 2017.

Moore, W. S.: Determining coastal mixing rates using radium isotopes, Cont. Shelf Res., 20, 1993-2007, 2000.

Murphy, E. J., Trathan, P. N., Watkins, J. L., Reid, K., Meredith, M. P., Forcada, J., Thorpe, S. E., Johnston, N. M., and Rothery, P. Climatically driven fluctuations in Southern Ocean ecosystems, P. Roy. Soc. B-Biol. Sci., 274, 3057-3067, 2007.

Nielsdóttir, M. C., Bibby, T. S., Moore, C. M., Hinz, D. J., Sanders, R., Whitehouse, M., Korb, R., and Achterberg, E. P.: Seasonal and spatial dynamics of iron availability in the Scotia Sea, Mar. Chem., 130-131, 62-72, 2012.

Pakhomova, S. V., Hall, P. O. J., Kononets, M. Y., Rozanov, A. G., Tengberg, A., and Vershinin, A. V.: Fluxes of iron and manganese across the sediment-water interface under various redox conditions, Mar. Chem., 107, 319-331, 2007.

Planquette, H., Statham, P. J., Fones, G. R., Charette, M. A., Moore, C. M., Salter, I., Nedelec, F. H., Taylor, S. L., French, M., Baker, A. R., Mahowald, N., and Jickells, T. D.: Dissolved iron in the vicinity of the Crozet Islands, Southern Ocean, Deep-Sea Res. Pt. II, 54, 1999-2019, 2007.

Planquette, H., Sanders, R., Statham, P. J., Morris, P. J., and Fones, G. R.: Fluxes of particulate iron from the upper ocean around the Crozet Islands: A naturally iron-fertilized environment in the Southern Ocean, Global Biogeochem. Cy., 25, 1-12, 2011.

Pollard, R. T., Salter, I., Sanders, R. J., Lucas, M. I., Moore, C. M., Mills, R. A., Statham, P. J., Allen, J. T., Baker, A. R., Bakker, D. C. E., Charette, M. A., Fielding, S., Fones, G. R., French, M., Hickman, A. E., Holland, R. J., Hughes, J. A., Jickells, T. D., Lampitt, R. S., Morris, P. J., Nedelec, F. H., Nielsdottir, M., Planquette, H., Popova, E. E., Poulton, A. J., Read, J. F., Seeyave, S., Smith, T., Stinchcombe, M., Taylor, S., Thomalla, S., Venables, H. J., Williamson, R., and Zubkov, M. V.: Southern Ocean deep-water carbon export enhanced by natural iron fertilization, Nature, 457, 577-580, 2009.

Raiswell, R. and Canfield, D. E.: The Iron Biogeochemical Cycle Past and Present, Geochem. Perspect., 1, 1-2, 2012.

Raiswell, R., Benning, L. G., Tranter, M., and Tulaczyk, S.: Bioavailable iron in the Southern Ocean: the significance of the iceberg conveyor belt, Geochem. T., 9, 1-9, 2008.

Rapp, I., Schlosser, C., Rusiecka, D., Gledhill, M., and Achterberg, E. P.: Automated preconcentration of $\mathrm{Fe}, \mathrm{Zn}, \mathrm{Cu}, \mathrm{Ni}, \mathrm{Cd}, \mathrm{Pb}$, $\mathrm{Co}$, and $\mathrm{Mn}$ in seawater with analysis using high-resolution sector field inductively-coupled plasma mass spectrometry, Anal. Chim. Acta, 976, 1-13, 2017.

Ratnarajah, L., Lannuzel, D., Townsend, A. T., Meiners, K. M., Nicol, S., Friedlaender, A. S., and Bowie, A. R.: Physical speciation and solubility of iron from baleen whale faecal material, Mar. Chem., 194, 79-88, 2017.

Sato, M., Takeda, S., and Furuya, K.: Iron regeneration and organic iron(III)-binding ligand production during in situ zooplankton grazing experiment, Mar. Chem., 106, 471-488, 2007. 
Schlosser, C., De La Rocha, C. L., and Croot, P. L.: Effects of iron surface adsorption and sample handling on iron solubility measurements, Mar. Chem., 127, 48-55, 2011.

Schmidt, K., Atkinson, A., Steigenberger, S., Fielding, S., Lindsay, M. C. M., Pond, D. W., Tarling, G. A., Klevjer, T. A., Allen, C. S., Nicol, S., and Achterberg, E. P.: Seabed foreaging by Antarctic krill: Implications for stock assessment, bentho-pelagic coupling, and the vertical transfer of iron, Limnol. Oceanogr., 56, 14111428, 2011.

Schmidt, K., Schlosser, C., Atkinson, A., Fielding, S., Venables, H. J., Waluda, C. M., and Achterberg, E. P.: Zooplankton gut passage mobilises lithogenic iron for ocean productivity, Curr. Biol., 26, 1-7, 2016.

Strzepek, R., Maldonado, M. T., Hunter, K. A., Frew, R. D., and Boyd, P. W.: Adaptive strategies by Southern Ocean phytoplankton to lessen iron limitation: Uptake of organically complexed iron and reduced cellular iron requirements, Limnol. Oceanogr., 56, 1983-2002, 2011.

Tagliabue, A., Sallee, J.-B., Bowie, A. R., Levy, M., Swart, S., and Boyd, P. W.: Surface-water iron supplies in the Southern Ocean sustained by deep winter mixing, Nat. Geosci., 7, 314-320, 2014.

Tsuda, A., Saito, H., Machida, R. J., and Shimode, S.: Meso- and microzooplankton responses to an in situ iron fertilization experiment (SEEDS II) in the northwest subarctic Pacific, Deep-Sea Res. Pt. II, 56, 2767-2778, 2009.
Wedepohl, K. H.: The composition of the continental crust, Geochim. Cosmochim. Ac., 59, 1217-1232, 1995.

Wells, M. L., Mayer, L. M., Donard, O. F. X., Sierra, M. M. D., and Ackelson, S. G.: The Photolysis Of Colloidal Iron In The Oceans, Nature, 353, 248-250, 1991.

Whitehouse, M. J., Korb, R. E., Atkinson, A., Thorpe, S. E., and Gordon, M.: Formation, transport and decay of an intense phytoplankton bloom within the High-Nutrient Low-Chlorophyll belt of the Southern Ocean, J. Mar. Syst., 70, 150-167, 2008.

Wing, S. R., Jack, L., Shatova, O., Leichter, J. J., Barr, D., Frew R. D., and Gault-Ringold, M.: Seabirds and marine mammals redistribute bioavailable iron in the Southern Ocean, Mar. Ecol.Prog. Ser., 510, 1-13, 2014.

Wolanski, E. J. and Delesalle, B.: Upwelling by internal waves, Tahiti, French Polynesia, Cont. Shelf Res., 15, 357-368, 1995.

Yoshida, M., Kuma, K., Iwade, S., Isoda, Y., Takata, H., and Yamada, M.: Effect of aging time on the availability of freshly precipitated ferric hydroxide to costal marine diatoms, Mar. Biol., 149, 379-392, 2006. 